\title{
ENHANCEMENT OF PLANT GROWTH, CHEMICAL COMPOSITION AND SECONDARY METABOLITES OF ESSENTIAL OIL OF SALT- STRESSED CORIANDER (CORIANDRUM SATIVUM L.) PLANTS USING SELENIUM, NANO-SELENIUM, AND GLYCINE BETAINE
}

\author{
R.G. El-Kinany ${ }^{*}$, S.H.M. Berengi ${ }^{* *}$, A.N.K. Nassar ${ }^{* * *}$ and A. El-Batal ${ }^{* * * *}$ \\ * Hort. Dept. (Floriculture and Ornamental Plants), Damanhour University, Damanhour, El-Beheira, Egypt. \\ ${ }^{* *}$ Hort. Dept. (Vegetable Crops), Damanhour University, Damanhour, El-Beheira, Egypt. \\ ${ }^{* * *}$ Plant Protection Dept., Fac. Agric., Damanhour University, Damanhour, El-Beheira, Egypt. \\ ${ }^{* * * *}$ Drug Radiation Research Department, National Center for Radiation Research and Technology (NCRRT), \\ Atomic Energy Authority, Cairo, Egypt.
}

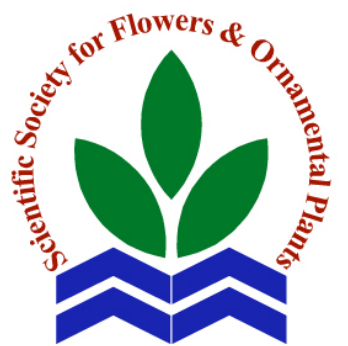

Scientific J. Flowers \& Ornamental Plants, 6(3):151-173 (2019).

Received: 2/12/2019 Accepted: $19 / 12 / 2019$

\begin{abstract}
Two pot experiments were carried out under greenhouse conditions during the two successive winter seasons of 2017/2018 and 2018/2019 to enhance the performance of coriander (Coriandrum sativum L.) plants under salt stress conditions $(\mathrm{NaCl}$ at 0 , 25, 50 and $75 \mathrm{mM}$ ). Along with the possibility of enhancing the plant growth, chemical composition, and secondary metabolites of essential oils. Foliar applications of selenium ( 25 and $50 \mathrm{ppm}$ ), nano selenium ( 25 and $50 \mathrm{ppm}$ ), glycine betaine (5 and $10 \mathrm{mM}$ ), and distilled water (control treatment) were applied on $C$. sativum plants. The foliage and root growth, chemical composition, and secondary metabolites of essential oils of coriander plants grown under salt stress were examined. The obtained results of the two seasons revealed that salt stress had significant deleterious effects on vegetative growth, fruit yield, essential oil yield, secondary components, and leaves chemical composition, while it enhanced the electrolyte leakage, proline content, $\mathrm{Na}^{+}$and $\mathrm{Cl}^{-}$of the leaves. Generally, the tested treatments: selenium, nano selenium, and glycine betaine varied in their significant effects on the studied characters. Selenium and glycine betaine treatments were more effective in improving coriander plants to salinity stress where they significantly increased almost all the studied parameters under saline compared to the control.
\end{abstract}

Key words: Coriander, selenium, selenium nanoparticles, glycine betaine, salt stress.

\section{INTRODUCTION}

Coriander (Coriandrum sativum L.) is one of the valuable medicinal annual herbs that belong to the Umbelliferae (Apiaceae) family (Evans 2002). The fresh leaves and the dried fruits of coriander are the most popular parts used in cooking as flavoring agents. In folk medicine, coriander is used to cure disorders of digestive, respiratory and urinary systems because of its diaphoretic, diuretic, carminative, and stimulant activities (Sahib et al., 2013). The essential oil is known for its inhibition activity against Gram-positive and -negative bacteria (Silva et al., 2011), yeasts and molds (Soares et al., 2012). The essential oil content is up to $1 \%$, and linalool is the main component (Neffati et al., 2011). The coriander essential oils content and chemical composition are significantly affected by different factors including genetic (Nejad Ebrahimi et al., 


\section{R.G. El-Kinany et al.}

2010), cultivation (Zheljazkov et al., 2008) as well as the abiotic stress, such as salinity (Neffati and Marzouk 2009).

Salinity stress is an important environmental stress factor that limits agricultural production. It is a global ecothreat to sustainable agriculture and is getting increased with time because of water shortage. According to the latest statistics, $20 \%$ of farmland in the world is faced with the salinity problem. Salinity lowers the osmotic potential of soil solution and affects the plant growth through nutritional and hormonal imbalance and induction of oxidative stress, or a combination of these factors (Rahnama et al., 2010). It significantly reduces the ability of plants to take up water causing a reduction in plant growth, ineffectiveness of stomata closure, inhibition of photosynthesis mechanism, imbalance in nutrient concentrations in the plant tissues, and yield reduction (Elhindi et al., 2016).

One strategy to increase tolerance of plants including coriander against salinity is the utilization of several compatible solutes such as selenium (Se), nano-selenium (nanoSe), and glycine betaine (GB). Selenium, a non-essential element for plants, many studies have shown that at low concentrations of Se exerts beneficial effects on the growth and stress tolerance of plants by enhancing their antioxidative capacity (Kaur and Nayyar, 2015). Also, Se might improve salt tolerance, transpiration rate, decline the osmotic potential, uphold turgor or the activity of antioxidant enzymes, stimulate the accumulation of free amino acids and total soluble sugars, and enhance the plant growth (Nawaz et al., 2015). In soil, selenate and selenite are the main sources of Se and may be efficiently uptake by plants (Liu et al., 2017).

Moreover, the nano-forms of minerals are characterized by unique physicochemical characteristics by which triggering especial responses differ from that of the bulk type (Asgari-Targhi et al., 2018). Nano- selenium could be used as an additional fertilizer for improving the productivity of crops. Thus, it was recorded that there is a good opportunity for the mediation of selenium nanotechnology in the area of plant nutrition and fertilizers (Mastronardi et al., 2015).

Alongside, glycine betaine is an amino acid derivative that accumulates in plant cells (Chen and Murata, 2002). Exogenous application of glycine betaine on the leaves or roots could be used to ameliorate plant abiotic stress (Kanechi et al., 2013). Foliar application of glycine betaine reduced the adverse effects of abiotic stresses by detoxification of reactive oxygen species, altering cellular osmotic, and protecting membrane integrity (Ahmad et al., 2012 and Hayat et al., 2012). Glycine betaine might also protect membrane functions from high concentrations of $\mathrm{Na}^{+}$and $\mathrm{Cl}^{-}$(Rhodes et al., 1989). Several reports demonstrated the positive effects of foliar application of glycine betaine on plant growth and final crop yield under salt stress such as in lettuce (Mostafakamal et al., 2016). Therefore, the current research was designed to investigate the response of growth, yield, essential oil yield and biochemical constituents of coriander after the foliar applications of selenium, nano-selenium, and glycine betaine under salt stress conditions.

\section{MATERIALS AND METHODS}

\section{Experimental design:}

During the winter seasons of $2017 / 2018$ and 2018/2019, two pot experiments were carried out under greenhouse conditions at the farm of Faculty of Agriculture, Damanhour University, El-Beheira Governorate, Egypt. The coriander uniform seeds of cv. Balady were sown on $20^{\text {th }}$ October in both seasons in plastic pots (30 $\mathrm{cm}$ diameter and $35 \mathrm{~cm}$ height), filled with $8.5 \mathrm{~kg}$ of sandy loam soil, and placed under greenhouse condition. After 15 days the seedlings were thinned to three uniformed seedlings in each pot.

Before seed sowing, soil samples were collected, and the physicochemical characteristics of the soil were determined 
according to the methods described by Jackson (1967) in both seasons (Table 1). The soil characteristic analyses were carried out at the Natural Resources and Agriculture Engineering Department, Faculty of Agriculture, Damanhour University.

The experimental design was a split-plot in a randomized complete block design, the saline water at $0,25,50$ and $75 \mathrm{mM}$ of $\mathrm{NaCl}$ represented in the main plots whereas, the foliar application of selenium at 25 and 50 ppm, nano selenium at 25 and $50 \mathrm{ppm}$, glycine betaine at 5 and $10 \mathrm{mM}$ and distilled water as a control treatment were randomly arranged in sub-plots. Each treatment was composed of five pots replicated three times with three plants for each pot. The study involved 20 treatments representing the combinations of four saline water and five treatments of foliar applications.

On November 11, (twenty-one-day old) uniformal plants of coriander were prepared for treatments. The plants were treated with saline water as a drench soil with 5 days interval throws the plant life. The value drench was $500 \mathrm{ml}$ per pot. The treatments with selenium, nano-selenium, and glycine betaine were applied twice as a spray application; the first one was carried out on the same day of irrigation with saline water and the second one was applied 15 days later. Spray application was conducted in the morning, and after the spray application, plants were irrigated at the end of the day. The soil surface was covered with polyethylene before the application of selenium, nano-selenium, and glycine betaine to avoid the falling of spray drips on the growing medium. The tested treatments were applied using a hand sprayer (capacity 2 liter) and non-ionic surfactant tween 80 at $0.05 \%(\mathrm{v} / \mathrm{v})$ was added to all concentrations to decrease the surface tension and increase the content angle of sprayed droplets. Each pot was sprayed individually, and the foliage of plant was moistened until the point of runoff. All the agricultural practices for coriander were applied according to the recommendation of the ministry of agriculture.

\section{Preparation of selenium nanoparticles:}

Selenious acid $(0.04 \mathrm{mM})$ under stirring was mixed with glutathione concentration as $0.2 \mathrm{mM}$ and $200 \mathrm{mg}$ bovine albumin solution in $100 \mathrm{ml}$ deionized water. The $\mathrm{pH}$ of the mixture was adjusted to 7.2 with $1.0 \mathrm{M}$ sodium hydroxide to initiate the reaction. The reaction lasted one hour under sonication condition, during which the red elemental Se and oxidized glutathione (GSSG) formed. The red solution was dialyzed against redistilled water for $96 \mathrm{~h}$ with the water changing every $24 \mathrm{~h}$ to separate GSSG from Nano-Se (Huang et al., 2003; El-Batal et al., 2012).

\section{Data recorded:}

\section{Plant growth characteristics:}

After 45 days from seed sowing, five plants from each treatment in each replicate

Table 1. Some physical and chemical properties of the experimental soil during both seasons of 2017/2018 and 2018/2019.

\begin{tabular}{ccccccc}
\hline \multirow{2}{*}{ Season } & Sand (\%) & Silt (\%) & Clay (\%) & Texture & $\begin{array}{c}\text { Bulk density } \\
\left(\mathbf{g ~ c m}^{-3}\right)\end{array}$ & $\begin{array}{c}\mathbf{C a C O}_{3} \\
\mathbf{( \% )}\end{array}$ \\
\hline $\mathbf{2 0 1 7 / 2 0 1 8}$ & 74.53 & 22.27 & 3.20 & Sandy loam & 1.56 & 2.40 \\
$\mathbf{2 0 1 8 / 2 0 1 9}$ & 74.65 & 21.79 & 3.56 & Sandy loam & 1.58 & 2.41 \\
\hline \multicolumn{7}{c}{ Chemical properties } \\
Season & $\mathbf{p H}$ & $\mathbf{E C}\left(\mathbf{d S m}^{-\mathbf{1}}\right)$ & $\begin{array}{c}\text { Organic } \\
\text { matter (\%) }\end{array}$ & $\mathbf{N}(\mathbf{p p m})$ & $\mathbf{P}(\mathbf{p p m})$ & $\mathbf{K}$ (ppm) \\
\hline $\mathbf{2 0 1 7 / 2 0 1 8}$ & 7.84 & 0.86 & 0.88 & 43.34 & 14.12 & 34.15 \\
$\mathbf{2 0 1 8} / \mathbf{2 0 1 9}$ & 7.86 & 0.91 & 0.92 & 51.62 & 15.13 & 36.20 \\
\hline
\end{tabular}




\section{R.G. El-Kinany et al.}

were randomly chosen and tagged to be used for data collection about the vegetative growth traits, namely; plant height, leaf length, herb fresh weight, root fresh weight and total fresh weight (g)/plant.

\section{Chemical measurements and analyses:}

Total leaf chlorophyll content (SPAD index) was measured using a SPAD-502 chlorophyll meter device (Konica Minolta, Kearney, NE, USA) according to Yadava (1986). The contents of ascorbic acid "vitamin C" (mg/100 g) were determined according to the method described by Singh (1988). Free proline content was determined in leaf fresh weight according to Bates et al. (1973). Electrolyte leakage was used to assess if the cell membranes were stable or not. It was measured according to the method explained by Lutts et al. (1999). Mineral analysis, total $\mathrm{N}$ in dry leaves were determined by the Kjeldahl method as described by Jones (1991). The contents of $\mathrm{K}, \mathrm{P}, \mathrm{Ca}, \mathrm{Na}$ and $\mathrm{Cl}$ were determined according to the methods described by Cottenie et al. (1982).

\section{Fruits essential oil content and its components:}

Coriander plants were harvested in both seasons at full fruits maturity stage. The fruits for each plant were harvested separately and weighed as grams per plant. The fruits were used to estimate the essential oil yield according to the method of Guenther (1961). The essential oil was extracted from coriander fruits using a Clevenger apparatus.

\section{Gas Chromatography-Mass Spectrum} analysis (GC-MS) of essential oil constituents:

The essential oil of coriander fruits extracted from control treatment $(0 \mathrm{mM}$ $\mathrm{NaCl}$ ) and control treatment sprayed with 10 $\mathrm{mM}$ glycine betaine and $50 \mathrm{ppm}$ selenium in both seasons were identified using Agilent gas chromatography coupled with mass spectrometry (GC-MS). The sample was dissolved in hexane and injected at $250{ }^{\circ} \mathrm{C}$ (injector temperature) into a capillary column type HP-5 (30 m X $0.25 \mathrm{~mm}$ i.d, $0.25 \mu \mathrm{m}$ film thickness), using helium as a carrier gas at a flow rate of $1 \mathrm{ml} / \mathrm{min}$. The injected volume was $1 \mu \mathrm{l}$ and the injection mode used was the splitless mode. The oven temperature was raised from $35^{\circ} \mathrm{C}$ (hold for $3 \mathrm{~min}$ ) to $240{ }^{\circ} \mathrm{C}$ at the rate of $5{ }^{\circ} \mathrm{C} / \mathrm{min}$, then at the rate of $3{ }^{\circ} \mathrm{C} / \mathrm{min}$, raised to $280{ }^{\circ} \mathrm{C}$, hold for $3 \mathrm{~min}$. The interface temperature was 250 ${ }^{\circ} \mathrm{C}$; the ion source temperature was $200{ }^{\circ} \mathrm{C}$. The start time was $4 \mathrm{~min}$ and the end time was $61.33 \mathrm{~min}$. The mass and scan range was set at $\mathrm{m} / \mathrm{z}$ 35-800. Components of essential oils were identified by their retention time and matching of the mass spectra with those of NIST and Wiley libraries database.

\section{Statistical analysis:}

All obtained data were statistically analyzed by Statistical Analysis Systems (Costat, 2008) and significant means were compared by the Tukey's test at 0.05 probability.

\section{RESULTS AND DISCUSSION}

\section{Plant growth characters:}

The data showing the main effects of the two studied factors (different salinity concentrations and different levels of "selenium, nano-selenium, and glycine betaine") and their interactions on plant growth of coriander plants during the two growing seasons of 2017/2018 and 2018/2019 were presented in Tables (2 and $3)$. Regarding the main effect of salt stress on plant growth parameters, data in Table (2) showed that plant height, leaf length, herb fresh weight, root fresh weight and total fresh weight of coriander plants were significantly decreased with increasing level of $\mathrm{NaCl}$ up to $75 \mathrm{mM}$ in both seasons. The greatest reduction of plant growth parameters was obtained under the highest concentration of $\mathrm{NaCl}$ "75 mM" in both seasons. Under high concentration of $\mathrm{NaCl}$ stress the estimated decuction percentages in plant height, leaf length, herb fresh weight, root fresh weight, and total fresh weight were 46.33 and 46.77, 19 and 23.46, 60.93 and 41.32, 50.46 and 31.40, and 59.87 
Table 2. The main effect of different salinity concentrations and different levels of selenium (Se), nano-selenium (Nano-Se), and glycine betaine (GB) on plant growth parameters of coriander plants during the two seasons of 2017/2018 $\left(1^{\text {st }}\right)$ and $2018 / 2019\left(2^{\text {nd }}\right)$.

\begin{tabular}{|c|c|c|c|c|c|c|c|c|c|c|}
\hline \multirow[t]{2}{*}{ Saline water } & \multicolumn{2}{|c|}{$\begin{array}{l}\text { Plant height } \\
\text { (cm) }\end{array}$} & \multicolumn{2}{|c|}{$\begin{array}{l}\text { Leaf length } \\
\text { (cm) }\end{array}$} & \multicolumn{2}{|c|}{$\begin{array}{l}\text { Herb fresh weight } \\
\text { (g)/plant }\end{array}$} & \multicolumn{2}{|c|}{$\begin{array}{l}\text { Root fresh weight } \\
\text { (g)/plant }\end{array}$} & \multicolumn{2}{|c|}{$\begin{array}{l}\text { Total fresh weight } \\
\text { (g)/plant }\end{array}$} \\
\hline & $1^{\text {st }}$ & $2^{\text {nd }}$ & $1^{\text {st }}$ & $2^{\text {nd }}$ & $1^{\text {st }}$ & $2^{\text {nd }}$ & $1^{\text {st }}$ & $2^{\text {nd }}$ & $1^{\text {st }}$ & 2nd \\
\hline \multicolumn{11}{|c|}{ Salt stress } \\
\hline $\mathbf{0} \mathbf{~ m M}$ & $52.88 \mathrm{~A}$ & 500 & $19.05 \mathrm{~A}$ & $0 \mathrm{~A}$ & & & $n$ & & $4 \mathrm{~A}$ & $4 \mathrm{~A}$ \\
\hline 25 I & B & B & $18.43 \mathrm{~A}$ & $+B$ & & & B & & $5 \mathrm{~B}$ & \\
\hline & $36.05 \mathrm{C}$ & $35.00 \mathrm{C}$ & $16.86 \mathrm{~B}$ & $\mathrm{C}$ & 5.8 & & $\mathrm{C}$ & & $9 \mathrm{C}$ & $\mathrm{C}$ \\
\hline & 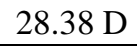 & $7.11 \mathrm{D}$ & $15.43 \mathrm{C}$ & $15.69 \mathrm{D}$ & & $5.41 \mathrm{D}$ & & & $\mathrm{D}$ & \\
\hline \multicolumn{11}{|c|}{ Selenium, nano-selenium, and glycine betaine } \\
\hline Control & $35.42 \mathrm{D}$ & $34.55 \mathrm{E}$ & $15.83 C$ & $13.60 \mathrm{D}$ & $4.48 \mathrm{E}$ & $5.22 \mathrm{E}$ & $0.43 \mathrm{D}$ & $1.35 \mathrm{E}$ & $4.91 \mathrm{E}$ & $6.57 \mathrm{E}$ \\
\hline Se 1 & $39.88 \mathrm{C}$ & $39.25 \mathrm{C}$ & $17.25 \mathrm{~B}$ & 20.13 B & $5.15 \mathrm{DE}$ & 6.8 & $4 \mathrm{C}$ & 1.4 & $5.69 \mathrm{D}$ & $8.22 \mathrm{C}$ \\
\hline Se 2 & $42.13 \mathrm{~B}$ & $41.15 \mathrm{~B}$ & $18.83 \mathrm{~A}$ & 21 & 7.85 B & 8.02 B & $0.60 \mathrm{C}$ & 1.5 & $8.45 \mathrm{~B}$ & I B \\
\hline Nano-Se 1 & $38.63 \mathrm{C}$ & $37.58 \mathrm{D}$ & 17.17 B & $15.58 \mathrm{C}$ & $6.55 \mathrm{C}$ & $6.02 \mathrm{D}$ & $0.57 \mathrm{C}$ & $1.27 \mathrm{~F}$ & $7.11 \mathrm{C}$ & $7.29 \mathrm{D}$ \\
\hline Nano-Se 2 & $39.17 \mathrm{C}$ & $36.94 \mathrm{D}$ & 14.33 D & $15.66 \mathrm{C}$ & $5.24 \mathrm{D}$ & $6.04 \mathrm{D}$ & $0.42 \mathrm{D}$ & $1.26 \mathrm{~F}$ & $5.65 \mathrm{D}$ & $7.30 \mathrm{D}$ \\
\hline GB 1 & $42.50 \mathrm{~B}$ & $41.35 \mathrm{~B}$ & $18.75 \mathrm{~A}$ & $19.65 \mathrm{~B}$ & $9.38 \mathrm{~A}$ & $10.04 \mathrm{~A}$ & $1.59 \mathrm{~A}$ & $1.70 \mathrm{~A}$ & $10.97 \mathrm{~A}$ & $11.74 \mathrm{~A}$ \\
\hline GB 2 & $45.17 \mathrm{~A}$ & $43.58 \mathrm{~A}$ & $19.92 \mathrm{~A}$ & $21.68 \mathrm{~A}$ & $8.90 \mathrm{~A}$ & $9.88 \mathrm{~A}$ & $1.43 \mathrm{~B}$ & $1.59 \mathrm{~B}$ & $10.33 \mathrm{~A}$ & $11.47 \mathrm{~A}$ \\
\hline
\end{tabular}

$\mathbf{1}^{\text {st }}$ and $2^{\text {nd; }}$; first season and second season. Means were compared using Tukey's Honest Significant Difference test $(P \leq 0.05) ; n=3$; Means with the same capital letters are no significantly different between different salinity concentrations or between different levels of selenium, nano-selenium, and glycine betaine.

and 39.76 compared to the control treatment for the first and second seasons, respectively.

The reduction in the plant growth characters as a result of salinity might be attributed to the accumulation of the salts in the soil, which increased the osmotic pressure of tissue cells and decreased the water absorption and/or redistribution of minerals and utilization (Mazher et al., 2006). In turn, it causes a reduction in cambium activity and maturation of smaller cell size (Wareing and Phillips, 1974). Also, increased salinity could reduce the endogenous level of IAA which may be critical to water movement through the root system of plants (Dunlap and Binzel 1996). The obtained results were in harmony with those reported by Langroudi and Sedaghathoor (2012) on Rosmarinus officinalis L.

Concerning the main effect of different rates of selenium, nano-selenium, and glycine betaine on the plant growth parameters, data in Table (2) indicated that spraying the coriander plants with these substances significantly increased plant growth parameters as compared to control in both seasons. However, the differences between control and nano-selenium treatment were the same in fresh weight in both seasons. The results, generally, showed that the highest values of plant height, leaf length, herb fresh weight, root fresh weight, and total fresh weight were recorded with glycine betaine treatments either with 10 or 5 $\mathrm{mM}$, respectively.

Generally, it could be pointed out that exogenous glycine betaine application might counteract the negative effects of high salinity on plant growth by maintaining osmotic adjustment (Ashraf and Foolad, 2007), and stabilizing many functions in the plants' cells, such as the oxygen-evolving PS-II complex (Harinasut et al., 1996), membranes quaternary structures of complex proteins (Murata et al., 1992) and enzymes such as rubisco. Habib et al. (2012) reported that the growth improvement due to glycine betaine could be related to high accumulation of $\mathrm{K}, \mathrm{Ca}$ and tissue glycine betaine, maintenance of high $\mathrm{K} / \mathrm{Na}$ ratio and 


\section{R.G. El-Kinany et al.}

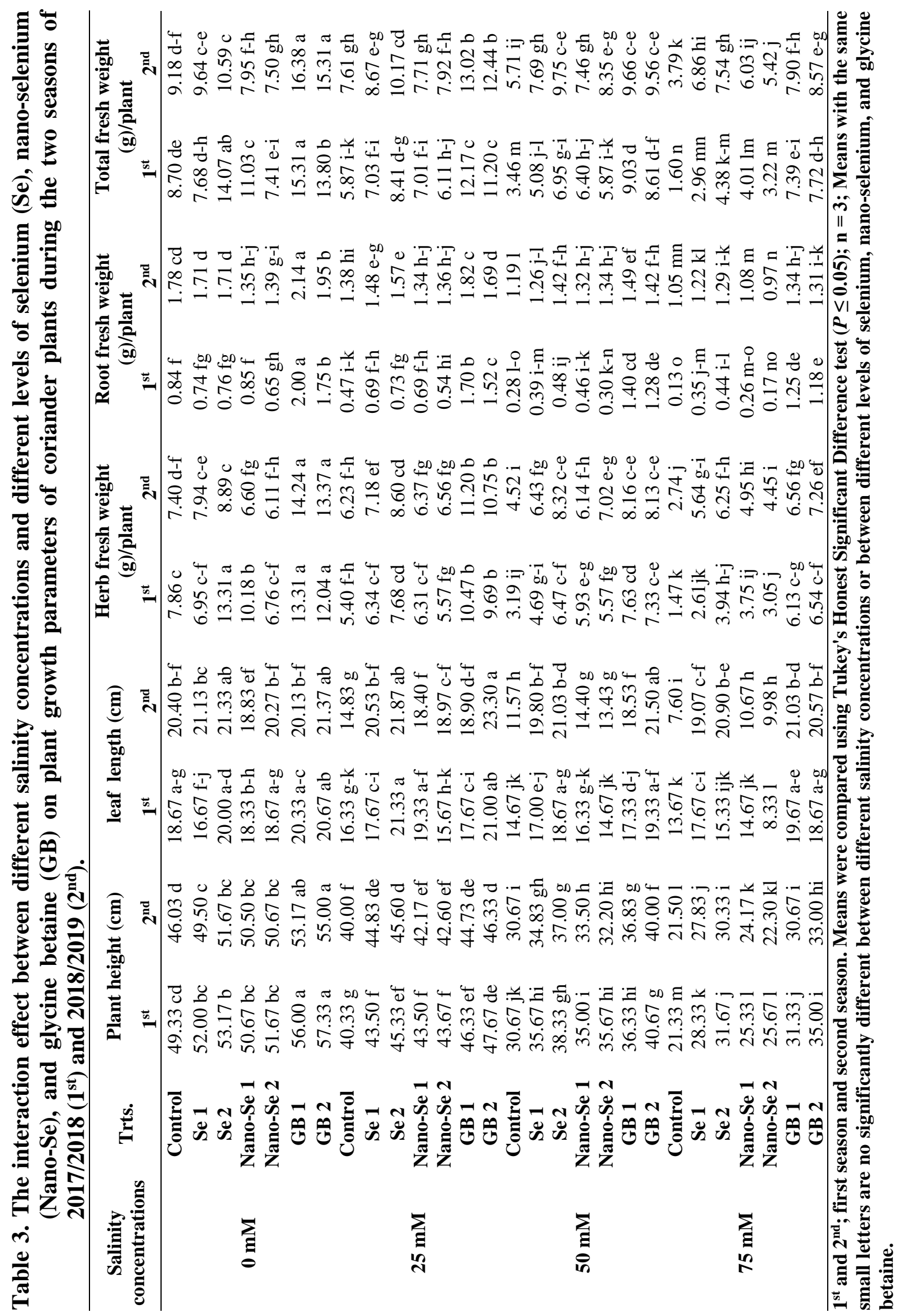


low accumulation of $\mathrm{Na}$ and $\mathrm{Cl}$ in the leaves. The obtained results of glycine betaine are in agreement with Agboma et al. (1996) on tobacco.

In parallel, selenium plays a critical role in the tolerance against some environmental stress, like acting as an antioxidant, alleviating oxidative stress (Mozafariyan et al., 2016). Also, it may be involved in the efficiency of the photosynthetic machinery, alleviating the chlorophyll degradation and preserving the chloroplast ultrastructure (Jiang et al., 2017). Moreover, seleniumtreated plants have increased proline content (Djanaguiraman et al., 2010). The aforementioned results of selenium are in good accordance with those postulated by Diao et al. (2014) on tomato.

The effect of the interaction between the different concentrations of salinity and rates of "selenium, nano-selenium, and glycine betaine" on plant growth characters was significant during both seasons (Table 3). The statistical analysis, generally, revealed that the highest values of plant height, herb fresh weight, root fresh weight and total fresh weight of coriander plants were achieved when spraying of coriander plants with glycine betaine under $0 \mathrm{mM}$ salinity in both seasons. On the other hand, the highest values of leaf length were achieved at the combined treatment of $25 \mathrm{mM}$ salinity and either $50 \mathrm{ppm}$ selenium for the first season or $5 \mathrm{mM}$ glycine betaine in the second season. Moreover, the application with glycine betaine or selenium under salt stress showed better performance in reducing the salinity adverse effect on vegetative growth of coriander, compared to the control and nanoselenium treatments.

\section{Chemical measurements and analyses:}

SPAD index, ascorbic acid, proline content, and electrolyte leakage:

Regarding the main effect of salt stress on SPAD index, ascorbic acid content, proline content, and electrolytic leakage of coriander plants, the obtained results in (Table 4) showed that SPAD index and ascorbic acid content were significantly

Table 4. The main effect of different salinity concentrations and different levels of selenium (Se), nano-selenium (Nano-Se), and glycine betaine (GB) on SPAD index, ascorbic acid, proline content and electrolyte leakage of coriander plants during the two seasons of 2017/2018 $\left(1^{\text {st }}\right)$ and 2018/2019 $\left(2^{\text {nd }}\right)$.

\begin{tabular}{|c|c|c|c|c|c|c|c|c|}
\hline \multirow{2}{*}{$\begin{array}{l}\text { Saline } \\
\text { water }\end{array}$} & \multicolumn{2}{|c|}{ SPAD index } & \multicolumn{2}{|c|}{$\begin{array}{l}\text { Ascorbic acid } \\
\text { (mg/100g) }\end{array}$} & \multicolumn{2}{|c|}{$\begin{array}{l}\text { Proline } \\
\text { (mg/g) }\end{array}$} & \multicolumn{2}{|c|}{$\begin{array}{c}\text { Electrolyte leakage } \\
(\%)\end{array}$} \\
\hline & $1^{\text {st }}$ & $2^{\text {nd }}$ & $1^{\text {st }}$ & $2^{\text {st }}$ & $1^{\text {nd }}$ & $2^{\text {nd }}$ & $1^{\text {st }}$ & $2^{\text {nd }}$ \\
\hline \multicolumn{9}{|c|}{ Salt stress } \\
\hline $0 \mathrm{mM}$ & $41.20 \mathrm{~A}$ & $42.26 \mathrm{~A}$ & 49.19 A & $49.03 \mathrm{~A}$ & $45.76 \mathrm{D}$ & $45.64 \mathrm{D}$ & $17.73 \mathrm{C}$ & 17.71 D \\
\hline $25 \mathrm{mM}$ & $40.31 \mathrm{AB}$ & 39.38 B & $42.17 \mathrm{~B}$ & $40.57 \mathrm{~B}$ & $56.03 \mathrm{C}$ & $57.96 \mathrm{C}$ & $20.42 \mathrm{C}$ & $21.80 \mathrm{C}$ \\
\hline $50 \mathrm{mM}$ & $41.08 \mathrm{AB}$ & $37.84 \mathrm{C}$ & $37.11 \mathrm{C}$ & $36.61 \mathrm{C}$ & $62.46 \mathrm{~B}$ & $62.40 \mathrm{~B}$ & $28.41 \mathrm{~B}$ & 29.46 B \\
\hline $75 \mathrm{mM}$ & $40.00 \mathrm{~B}$ & $37.99 \mathrm{C}$ & $35.88 \mathrm{D}$ & $36.08 \mathrm{C}$ & $69.21 \mathrm{~A}$ & $67.89 \mathrm{~A}$ & $41.46 \mathrm{~A}$ & $39.03 \mathrm{~A}$ \\
\hline \multicolumn{9}{|c|}{ Selenium, nano-selenium, and glycine betaine } \\
\hline Control & $38.85 \mathrm{~B}$ & $36.57 \mathrm{C}$ & $37.48 \mathrm{D}$ & $35.88 \mathrm{C}$ & $61.40 \mathrm{~A}$ & $64.18 \mathrm{~A}$ & $33.12 \mathrm{~A}$ & $31.72 \mathrm{~A}$ \\
\hline Se 1 & $41.84 \mathrm{~A}$ & $40.16 \mathrm{AB}$ & $42.24 \mathrm{AB}$ & $41.20 \mathrm{AB}$ & $53.22 \mathrm{C}$ & $54.58 \mathrm{D}$ & $24.85 \mathrm{C}$ & $23.94 \mathrm{D}$ \\
\hline Se 2 & $41.67 \mathrm{~A}$ & $40.32 \mathrm{AB}$ & $41.02 \mathrm{BC}$ & $42.58 \mathrm{~A}$ & $56.30 \mathrm{~B}$ & $53.63 \mathrm{D}$ & $25.32 \mathrm{BC}$ & $22.30 \mathrm{E}$ \\
\hline Nano-Se 1 & $40.58 \mathrm{AB}$ & $37.83 \mathrm{C}$ & $40.30 \mathrm{C}$ & $40.15 \mathrm{~B}$ & $58.26 \mathrm{~B}$ & $58.64 \mathrm{C}$ & $26.24 \mathrm{BC}$ & $28.63 \mathrm{~B}$ \\
\hline Nano-Se 2 & $39.56 \mathrm{AB}$ & $38.65 \mathrm{BC}$ & $42.29 \mathrm{AB}$ & $40.22 \mathrm{~B}$ & $63.46 \mathrm{~A}$ & $62.34 \mathrm{~B}$ & 28.26 B & $31.19 \mathrm{~A}$ \\
\hline GB 1 & $40.87 \mathrm{AB}$ & $40.77 \mathrm{~A}$ & $41.12 \mathrm{BC}$ & $41.37 \mathrm{AB}$ & $57.56 \mathrm{~B}$ & $57.56 \mathrm{C}$ & $25.04 \mathrm{C}$ & $25.04 \mathrm{CD}$ \\
\hline GB 2 & $41.26 \mathrm{~A}$ & $41.28 \mathrm{~A}$ & $43.14 \mathrm{~A}$ & $42.59 \mathrm{~A}$ & $58.39 \mathrm{~B}$ & $58.37 \mathrm{C}$ & $26.19 \mathrm{BC}$ & $26.19 \mathrm{C}$ \\
\hline
\end{tabular}

$\mathbf{1}^{\text {st }}$ and $2^{\text {nd; }}$; first season and second season. Means were compared using Tukey's Honest Significant Difference test $(P \leq 0.05) ; n=3$; Means with the same capital letters are no significantly different between different salinity concentrations or between different levels of selenium, nano-selenium, and glycine betaine. 


\section{R.G. El-Kinany et al.}

decreased with increasing level of salinity up to the highest concentration in both seasons. On the other hand, proline content and electrolytic leakage were significantly increased with increasing levels of salinity in both seasons. The estimated percentages decrease of SPAD index and ascorbic acid content were 2.91 and 10.1 and 27.06 and $26.41 \%$, for the first and second season, respectively. The estimated percentages of increase in proline content and electrolytic leakage were 51.25 and 48.75 and 133.84 and $120.38 \%$ as compared to the control treatment for the first and second season, respectively.

The reduction of chlorophyll contents under salt stress was related to the rapid maturing of leaves (Yeo et al., 1991). Also, swelling of thylakoids was induced at the early stage of the damage when plants are affected by salinity and leads to a reduction in chlorophyll synthesis (Yamane et al., 2003). It might be due to ion accumulation and functional disorders observed during the stoma opening and closing under salinity stress (Molazem et al., 2010). The net photosynthesis, transpiration rate, and stomatal conductance were significantly affected by salinity due to changes in chlorophyll content and chlorophyll fluorescence, damage of photosynthetic apparatus and chloroplast structure (Baki et al., 2000, Fidalgo et al., 2004). The obtained results are in harmony with those reported by Heidari (2012) on basil.

Ascorbic acid or vitamin $\mathrm{C}$ is a small, water-soluble, antioxidant molecule that acts as a primary substrate in the cyclic pathway of enzymatic detoxification of $\mathrm{H}_{2} \mathrm{O}_{2}$ (Beltagi, 2008). Decreased ascorbic acid content under salt stress has also been reported by Seth et al. (2007) on wheat and Emam and Helal (2008) on Linum usitatissimum plants. According to these studies, a decrease in ascorbate content might be one of the reasons why salinized coriander seedlings were unable to tolerate salt stress.

Electrolyte leakage was enhanced with increasing salinity levels as compared to the control. This phenomenon was already observed by several authors Hu et al. (2013) on melon and Khan et al. (2013) on cucumber. The increase in proline content with increasing salt stress is one of the defense mechanisms in which stressed plants used to reduce cell osmotic potential, which resulted in increasing cell water uptake with concomitant increases in both cell turgidity and its activity (Khalil and El-Noemani 2012). These results seemed to be in agreement with those reported by Heidari and Akbari (2012) on two marigold genotypes and Kaya et al. (2013) on maize.

Concerning the main effect of different rates of selenium, nano-selenium, and glycine betaine on SPAD index, ascorbic acid, proline content and electrolyte leakage of coriander plants, data in Table (4) indicated that treated-coriander plants had significantly increased SPAD index and ascorbic acid and decreased proline and electrolyte leakage compared to control (spraying with tap water) in both seasons. The highest mean value of SPAD index was observed at 25 or $50 \mathrm{ppm}$ selenium and 10 $\mathrm{mM}$ glycine betaine in the first season and 5 or $10 \mathrm{mM}$ glycine betaine in the second season compared to other treatments. The highest mean values of ascorbic acid were observed at $10 \mathrm{mM}$ glycine betaine in both seasons and $50 \mathrm{ppm}$ selenium in the second season only. Also, the highest mean value of proline content and electrolyte leakage was observed at control treatment in both seasons and $50 \mathrm{ppm}$ nano selenium in the first season for proline and the second season for electrolyte leakage. But, the lowest mean values of proline content were observed at 25 ppm selenium in both seasons and 50 ppm selenium in the second season and the lowest mean values of electrolyte leakage were observed at $25 \mathrm{ppm}$ selenium and 5 $\mathrm{mM}$ glycine betaine in the first season and $50 \mathrm{ppm}$ selenium in the second season.

Results of selenium foliar application on ascorbic acid content in coriander plants indicated that the incremental rise in the selenium dosage to the coriander plants led 
to the synthesis of ascorbic acid. Our findings were in agreement with those reported by Ríos et al. (2008) who found that ascorbic acid content in lettuce leaves increased gradually with increasing selenium supplied to the plants, via foliar spray or fertigation. Also, the increment of ascorbic acid under glycine betaine foliar application was reported by Shams etal. (2016) on lettuce.

Selenium application decreased significantly the electrolyte leakage of salt stress indicating its important role concerning membrane integrity in coriander seedlings. A decrease in electrolyte leakage in response to increasing selenium treatments was also observed by Kong et al. (2005) in salt-tolerant sorrel seedlings; they reported that the reduced electrolyte leakage may be a direct consequence of selenium treatment. Glycine betaine exogenous application reduces oxidative damage caused by salt stress and helped to reduce electrolyte leakage. Similar findings were reported in many earlier studies Kaya et al. (2013) on maize.

Leaf proline concentrations were significantly decreased due to the foliar application of glycine betaine. Likewise, Heuer (2003) and Demiral and Türkan (2006) also indicated that exogenously applied glycine betaine significantly reduced the proline content in salt-stressed tomato and rice plants, respectively. The reduction in proline content due to foliar application of glycine betaine might be due to the interference of glycine betaine in the process of osmotic adjustment by proline accumulation. Regarding the effect of selenium on proline content, it was recorded by Al-Kazzaz (2018) who indicated that there was a significant decrease in the proline content in broad bean plants by increasing selenium from 0 to $20 \mathrm{mg} / \mathrm{l}$. However, lower proline content of selenium treated plants under salinity suggests that they were less strained due to some ameliorating mechanisms.
Glycine betaine exogenous application improved the availability of advantageous ions like $\mathrm{Mg}^{++}$and $\mathrm{K}^{+}$, and reduced the uptake of injurious ions such as $\mathrm{Na}^{+}$and $\mathrm{Cl}^{-}$, resulting in an increased photosynthetic capacity (Shaddad, 1990). Makela et al. (1998 and 1999) reported that the enhancement of photosynthesis after glycine betaine application under salinity conditions may be due to the reduction of photorespiration rate, greater gas exchange and higher carbon availability for photosynthesis. The obtained results are in agreement with Saeed et al. (2016) on okra. On the other hand, Diao et al. (2014) reported that selenium alleviates salt-induced stress in tomato seedlings by regulating the antioxidant defense systems in the chloroplasts which are associated with the improvement of the photochemical efficiency of PSII.

The effect of the interaction between the different salinity concentrations and different rates of selenium, nano-selenium, and glycine betaine on SPAD index, ascorbic acid, proline content and electrolytic leakage of coriander plants was significant during both seasons (Table 5). The statistical analysis, generally, revealed that the highest values of SPAD index and ascorbic acid were recorded at the combined treatments of control and foliar spray with $25 \mathrm{ppm}$ selenium in both seasons or 5 and $10 \mathrm{mM}$ glycine betaine in the first season for SPAD index. The lowest values of the electrolytic leakage percentage and proline of coriander leaves had been obtained under glycine betaine treatment with the lowest salinity $(0$ $\mathrm{mM} \mathrm{NaCl}$ ), while the highest values of those measurements were observed for control treatment with the highest salinity concentration (75 $\mathrm{mM} \mathrm{NaCl}$ ).

\section{Leaves mineral content:}

Pertaining to the main effect of salt stress on leaves minerals content of coriander plants, the gained results presented in Table (6) showed that there was a positive relationship between $\mathrm{Na}^{+}$and $\mathrm{Cl}^{-}$content and increasing $\mathrm{NaCl}$ concentrations. As $\mathrm{NaCl}$ 
Table 5. The interaction effect between different salinity concentrations and different levels of selenium (Se), nano-selenium (Nano-Se), and glycine betaine (GB) on SPAD index, ascorbic acid, proline content and electrolyte leakage of coriander plants during the two seasons of 2017/2018 $\left(1^{\text {st }}\right)$ and $2018 / 2019\left(2^{\text {nd }}\right)$.

\begin{tabular}{|c|c|c|c|c|c|c|c|c|c|}
\hline \multirow{2}{*}{$\begin{array}{c}\text { Salinity } \\
\text { concentrations }\end{array}$} & \multirow[t]{2}{*}{ Trts. } & \multicolumn{2}{|c|}{ SPAD index } & \multicolumn{2}{|c|}{$\begin{array}{l}\text { Ascorbic acid } \\
\text { (mg/100g) }\end{array}$} & \multicolumn{2}{|c|}{$\begin{array}{l}\text { Proline } \\
\text { (mg/g) }\end{array}$} & \multicolumn{2}{|c|}{$\begin{array}{c}\text { Electrolyte leakage } \\
(\%)\end{array}$} \\
\hline & & $1^{\text {st }}$ & $2^{\text {nd }}$ & $1^{\text {st }}$ & $2^{\text {nd }}$ & $1^{\text {st }}$ & $2^{\text {nd }}$ & $1^{\text {st }}$ & $2^{\text {nd }}$ \\
\hline \multirow{7}{*}{$0 \mathrm{mM}$} & Control & 40.47 a-c & $42.37 \mathrm{a}-\mathrm{d}$ & 46.20 c-e & $44.53 \mathrm{c}$ & $46.74 \mathrm{kl}$ & $47.68 \mathrm{jk}$ & $16.96 \mathrm{j}$ & $17.25 \mathrm{~m}-\mathrm{p}$ \\
\hline & Se 1 & $43.77 \mathrm{a}$ & $46.17 \mathrm{a}$ & $51.30 \mathrm{a}$ & $51.30 \mathrm{a}$ & $41.35 \mathrm{~m}$ & $44.71 \mathrm{kl}$ & $18.19 \mathrm{ij}$ & 15.36 op \\
\hline & Se 2 & $39.77 \mathrm{a}-\mathrm{d}$ & $44.64 \mathrm{ab}$ & $50.99 a b$ & $50.14 \mathrm{ab}$ & $43.02 \mathrm{~lm}$ & 42.131 & $17.64 \mathrm{ij}$ & $15.05 \mathrm{p}$ \\
\hline & Nano-Se 1 & 40.07 a-c & 40.57 b-h & $48.30 \mathrm{a}-\mathrm{d}$ & $47.66 \mathrm{~b}$ & $50.05 \mathrm{jk}$ & $47.35 \mathrm{k}$ & $17.77 \mathrm{ij}$ & $21.07 \mathrm{i}-\mathrm{k}$ \\
\hline & Nano-Se 2 & 40.77 a-c & $41.40 \mathrm{~b}-\mathrm{g}$ & $47.78 \mathrm{~b}-\mathrm{d}$ & $49.79 a b$ & $52.07 \mathrm{j}$ & $50.50 \mathrm{j}$ & 20.12 g-j & $21.96 \mathrm{i}-\mathrm{k}$ \\
\hline & GB 1 & 43.33 a & $40.20 \mathrm{~b}-\mathrm{h}$ & $49.31 \mathrm{a}-\mathrm{c}$ & $49.31 \mathrm{ab}$ & $43.50 \mathrm{~lm}$ & 43.531 & $16.94 \mathrm{j}$ & 16.94 n-p \\
\hline & GB 2 & $43.77 \mathrm{a}$ & $40.47 \mathrm{~b}-\mathrm{h}$ & $50.45 \mathrm{ab}$ & $50.45 \mathrm{ab}$ & $43.56 \mathrm{~lm}$ & 43.581 & $16.34 \mathrm{j}$ & $16.34 n-p$ \\
\hline \multirow{7}{*}{$25 \mathrm{mM}$} & Control & 40.00 a-c & 36.20 hi & 43.62 ef & $40.96 \mathrm{~d}-\mathrm{f}$ & $57.59 \mathrm{f}-\mathrm{i}$ & $63.23 \mathrm{ef}$ & $24.26 \mathrm{f}-\mathrm{i}$ & $24.90 \mathrm{~g}-\mathrm{i}$ \\
\hline & Se 1 & 40.13 a-c & 39.51 c-i & $45.18 \mathrm{~d}-\mathrm{f}$ & 41.19 c-e & $53.67 \mathrm{~h}-\mathrm{j}$ & $55.95 \mathrm{hi}$ & $18.29 \mathrm{ij}$ & 19.27 k-n \\
\hline & Se 2 & $40.57 \mathrm{a}-\mathrm{c}$ & $40.55 \mathrm{~b}-\mathrm{h}$ & $39.25 \mathrm{hi}$ & $43.73 \mathrm{~cd}$ & $52.98 \mathrm{ij}$ & $54.27 \mathrm{i}$ & $19.76 \mathrm{~h}-\mathrm{j}$ & 18.53 l-o \\
\hline & Nano-Se 1 & $42.27 \mathrm{a}-\mathrm{c}$ & 39.43 c-i & 38.77 hi & $38.44 \mathrm{f}-\mathrm{i}$ & $53.87 \mathrm{~h}-\mathrm{j}$ & $56.86 \mathrm{hi}$ & $20.15 \mathrm{~g}-\mathrm{j}$ & $23.27 \mathrm{~h}-\mathrm{j}$ \\
\hline & Nano-Se 2 & $39.13 \mathrm{a}-\mathrm{d}$ & $39.90 \mathrm{~b}-\mathrm{h}$ & 46.40 c-e & $38.27 \mathrm{f}-\mathrm{i}$ & $61.45 \mathrm{ef}$ & 62.73 ef & $19.82 \mathrm{~h}-\mathrm{j}$ & $25.98 \mathrm{gh}$ \\
\hline & GB 1 & $39.63 \mathrm{a}-\mathrm{d}$ & 39.63 c-h & $39.20 \mathrm{hi}$ & 39.53 e-h & 54.33 g-j & $54.33 \mathrm{i}$ & 20.24 g-j & $20.25 \mathrm{j}-\mathrm{m}$ \\
\hline & GB 2 & 40.47 & $40.47 \mathrm{~b}-\mathrm{h}$ & $42.73 \mathrm{fg}$ & $41.89 \mathrm{~d}-\mathrm{f}$ & $58.32 \mathrm{f}-\mathrm{h}$ & 58.32 gh & $20.40 \mathrm{~g}-\mathrm{j}$ & $20.43 \mathrm{i}-\mathrm{k}$ \\
\hline \multirow{7}{*}{$50 \mathrm{mM}$} & Control & $37.20 \mathrm{~cd}$ & $31.07 \mathrm{j}$ & $31.39 \mathrm{j}$ & $29.92 \mathrm{j}$ & $66.61 \mathrm{~cd}$ & 68.47 bc & $36.08 \mathrm{~cd}$ & $37.57 \mathrm{c}$ \\
\hline & Se 1 & $42.07 \mathrm{a}-\mathrm{c}$ & $37.03 \mathrm{f}-\mathrm{i}$ & $36.46 \mathrm{i}$ & 35.56 i & $57.17 \mathrm{f}-\mathrm{i}$ & $56.93 \mathrm{hi}$ & $25.14 \mathrm{f}-\mathrm{h}$ & 24.43 g-i \\
\hline & Se 2 & $42.57 \mathrm{ab}$ & $38.55 c-i$ & $37.73 \mathrm{hi}$ & $38.40 \mathrm{f}-\mathrm{i}$ & $61.19 \mathrm{ef}$ & 57.11 hi & $26.87 \mathrm{ef}$ & $25.29 \mathrm{gh}$ \\
\hline & Nano-Se 1 & $37.70 \mathrm{~b}-\mathrm{d}$ & $36.55 \mathrm{~g}-\mathrm{i}$ & $37.66 \mathrm{hi}$ & 37.32 g-i & $58.62 \mathrm{fg}$ & 63.35 ef & $26.41 \mathrm{e}-\mathrm{g}$ & $32.67 \mathrm{ef}$ \\
\hline & Nano-Se 2 & $43.50 \mathrm{a}$ & 37.15 e-i & $38.25 \mathrm{hi}$ & 36.80 g-i & 67.92 b-d & $65.22 \mathrm{de}$ & $32.17 \mathrm{de}$ & $34.04 \mathrm{de}$ \\
\hline & GB 1 & $41.97 \mathrm{a}-\mathrm{c}$ & $41.97 \mathrm{a}-\mathrm{e}$ & $38.16 \mathrm{hi}$ & $38.16 \mathrm{f}-\mathrm{i}$ & $63.80 \mathrm{de}$ & 63.80 ef & 27.17 ef & $27.19 \mathrm{~g}$ \\
\hline & GB 2 & $42.57 \mathrm{ab}$ & $42.57 \mathrm{a}-\mathrm{c}$ & $40.09 \mathrm{gh}$ & 40.09 e-g & $61.87 \mathrm{ef}$ & $61.90 \mathrm{f}$ & $24.92 \mathrm{f}-\mathrm{h}$ & 25.02 g-i \\
\hline \multirow{7}{*}{$75 \mathrm{mM}$} & Control & $34.87 \mathrm{~d}$ & $36.63 \mathrm{~g}-\mathrm{i}$ & $28.72 \mathrm{j}$ & $28.11 \mathrm{j}$ & $74.65 \mathrm{a}$ & $77.33 \mathrm{a}$ & $55.17 \mathrm{a}$ & $47.17 \mathrm{a}$ \\
\hline & Se 1 & $41.40 \mathrm{a}-\mathrm{c}$ & $37.93 \mathrm{c}-\mathrm{i}$ & $36.03 \mathrm{i}$ & 36.76 g-i & 60.69 ef & $60.73 \mathrm{fg}$ & 37.80 b-d & $36.69 \mathrm{~cd}$ \\
\hline & Se 2 & $40.20 \mathrm{a}-\mathrm{c}$ & $37.55 \mathrm{~d}-\mathrm{i}$ & $36.11 \mathrm{i}$ & $38.06 \mathrm{f}-\mathrm{i}$ & $68.01 \mathrm{~b}-\mathrm{d}$ & $61.01 \mathrm{fg}$ & $37.00 \mathrm{~b}-\mathrm{d}$ & $30.34 \mathrm{f}$ \\
\hline & Nano-Se 1 & $42.27 \mathrm{a}-\mathrm{c}$ & $34.77 \mathrm{ij}$ & $36.47 \mathrm{i}$ & 37.20 g-i & 70.49 a-c & $67.00 \mathrm{~cd}$ & 40.60 bc & $37.50 \mathrm{c}$ \\
\hline & Nano-Se 2 & $34.83 \mathrm{~d}$ & 36.17 hi & $36.73 \mathrm{hi}$ & $36.00 \mathrm{hi}$ & $72.40 \mathrm{ab}$ & 70.92 b & 40.93 bc & $42.78 \mathrm{~b}$ \\
\hline & GB 1 & $41.37 \mathrm{a}-\mathrm{c}$ & $41.27 \mathrm{~b}-\mathrm{g}$ & $37.79 \mathrm{hi}$ & $38.46 \mathrm{f}-\mathrm{i}$ & $68.57 \mathrm{bc}$ & 68.57 bc & $35.76 \mathrm{~cd}$ & $35.78 \mathrm{~cd}$ \\
\hline & GB 2 & $41.62 \mathrm{a}-\mathrm{c}$ & $41.63 \mathrm{a}-\mathrm{f}$ & $39.28 \mathrm{hi}$ & $37.94 \mathrm{f}-\mathrm{i}$ & $69.64 \mathrm{bc}$ & $69.67 \mathrm{bc}$ & $42.93 \mathrm{~b}$ & $42.95 \mathrm{~b}$ \\
\hline
\end{tabular}

$\mathbf{1}^{\text {st }}$ and $2^{\text {nd; }}$ first season and second season. Means were compared using Tukey's Honest Significant Difference test $(P \leq 0.05) ; n=3$; Means with the same small letters are no significantly different between different salinity concentrations or between different levels of selenium, nano-selenium, and glycine betaine.

concentrations increased the leaf content of $\mathrm{Na}^{+}$and $\mathrm{Cl}^{-}$were increased too. On the other hand, there was a clear negative relationship between $\mathrm{N}, \mathrm{P}, \mathrm{K}^{+}, \mathrm{Ca}^{2+}$ and $\mathrm{Mg}^{2+}$ content and $\mathrm{NaCl}$ concentrations. As $\mathrm{NaCl}$ concentrations increased, the leaf content of $\mathrm{N}, \mathrm{P}, \mathrm{K}^{+}, \mathrm{Ca}^{2+}$ and $\mathrm{Mg}^{2+}$ were decreased. Under high salinity concentration, the estimated reduction percentages of $\mathrm{N}, \mathrm{P}, \mathrm{K}^{+}$, $\mathrm{Ca}^{2+}$, and $\mathrm{Mg}^{2+}$ contents were 22.81 and 28.99, 37.93 and 37.29, 34.97 and 37.91, 18.71 and 18.49 , and 21.31 and $25.39 \%$ as compared to the control treatment for the first and second season, respectively (Table 6). But, the estimated percentage increment of $\mathrm{Na}^{+}$and $\mathrm{Cl}^{-}$content under high $\mathrm{NaCl}$ concentration was 294.64 and 312.73 and 260.92 and $314.87 \%$ as compared to the control treatment for the first and second season, respectively.

The negative effect of salt stress on mineral elements uptake could be attributed to the low osmotic potential of the soil solution due to the increased concentration of $\mathrm{NaCl}$ (Khaled and Fawy, 2011). Salinity reduced $\mathrm{N}, \mathrm{P}, \mathrm{K}^{+}, \mathrm{Ca}$ and $\mathrm{Mg}$ accumulation in plants (Navarro et al., 2001) due to the competitive process by Na (Lopez and Satti, 1996). Ionic imbalance occurs in the cells due to over-accumulation of $\mathrm{Na}$ and $\mathrm{Cl}$ and 


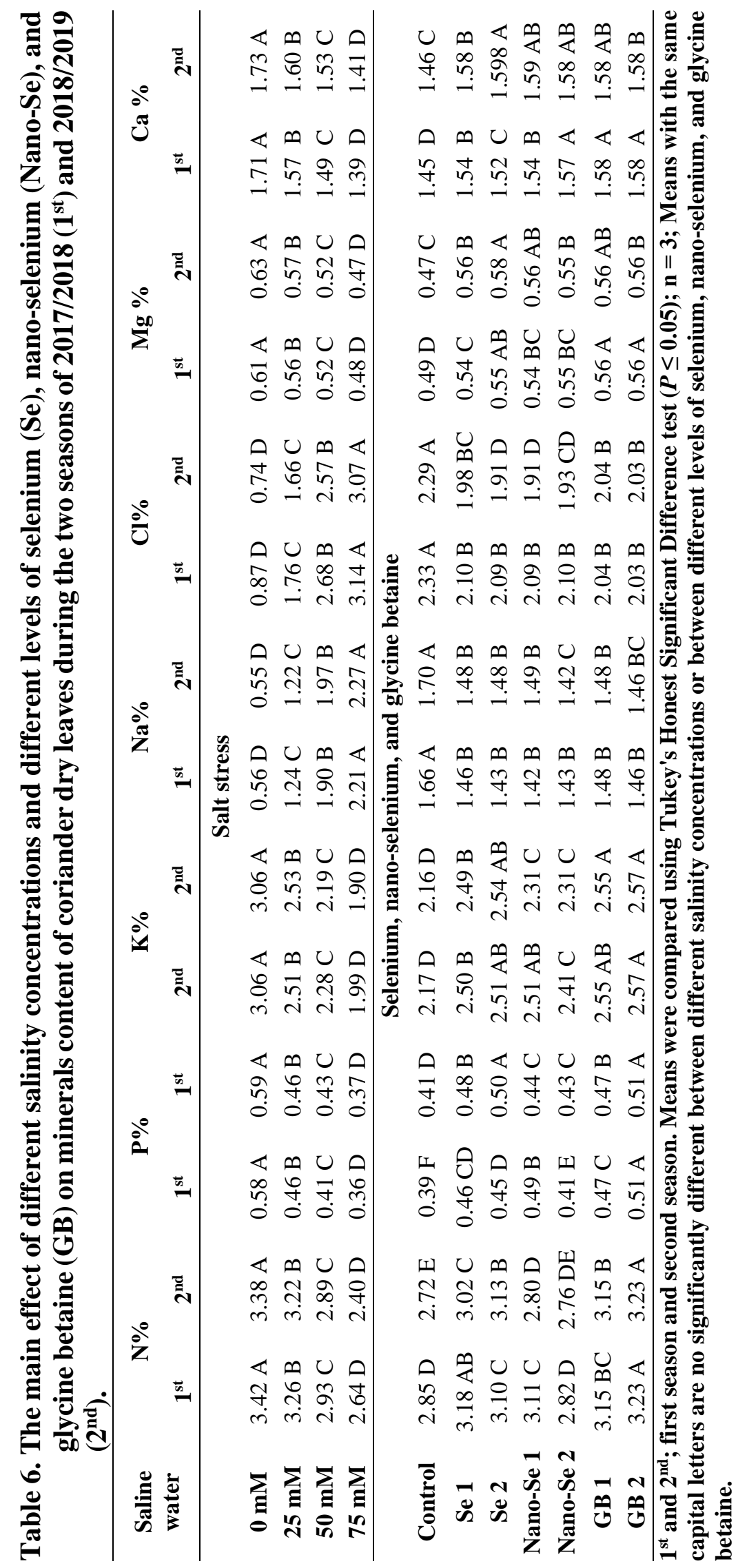




\section{R.G. El-Kinany et al.}

reduced uptake of other mineral nutrients, such as nitrogen leading to the suppression in growth (Karimi et al., 2005). The present results were in parallel with those reported by Elhindi et al. (2016) on coriander.

Regarding the main effect of different rates of selenium, nano-selenium, and glycine betaine on coriander leaves minerals content, data in Table (6) indicated that spraying coriander plants with selenium, nano-selenium, and glycine betaine significantly increased $\mathrm{N}, \mathrm{P}, \mathrm{K}^{+}, \mathrm{Ca}$ and $\mathrm{Mg}$ contents and decreased $\mathrm{Na}^{+}$and $\mathrm{Cl}^{-}$contents of coriander plants leaves as compared to control (spraying with tap water) in both seasons. The highest mean values of $\mathrm{N}, \mathrm{P}$ and $\mathrm{K}^{+}$contents were recorded at the application of glycine betaine at $10 \mathrm{mM}$ in both seasons. Also, the highest mean values of $\mathrm{Mg}$ content were recorded with glycine betaine at 5 and $10 \mathrm{mM}$ in both seasons and with selenium at $50 \mathrm{ppm}$ in the second season. The highest mean values of $\mathrm{Ca}$ content was recorded with glycine betaine at 5 and $10 \mathrm{mM}$ in both seasons and nano selenium at $50 \mathrm{ppm}$ in the first season and 50 ppm selenium in the second season. While, the lowest contents of $\mathrm{N}, \mathrm{P}, \mathrm{K}^{+}$, Ca and $\mathrm{Mg}$ were obtained with control. As for the sodium and chloride contents, the highest values were observed with control.

Exogenously application of glycine betaine improved the plant nutrient content of the salt-stressed coriander plants. While it decreased the concentration of $\mathrm{Na}$ and $\mathrm{Cl}$ elements under salinity conditions. The tendency for higher contents of $\mathrm{N}, \mathrm{P}$, and $\mathrm{K}$ in plants treated with glycine betaine under salinity conditions showed that plants could absorb more nutrients compared to untreated ones and this reflected on overall plant growth (Abdel-Mawgoud, 2017). These results were in harmony with earlier results in which glycine betaine treatments improved the uptake of nutrient elements but decreased the accumulation of $\mathrm{Na}$ (Habib et al., 2012 on okra). Foliar application of selenium led to increased absorption of $\mathrm{N}, \mathrm{P}$, $\mathrm{K}$, Ca and $\mathrm{Mg}$ and decreased absorption of
$\mathrm{Na}$ and $\mathrm{Cl}$ under salt stress conditions. Boghdady et al. (2017) found that foliar spraying with selenium at low concentrations had a positive effect on a significant increase of $\mathrm{N}, \mathrm{P}$ and $\mathrm{K}$ percentage in faba bean seeds.

The effect of the interaction between the different salinity concentrations and different rates of selenium, nano-selenium, and glycine betaine on leaves minerals content of coriander plants were significant during both seasons Table (7). The statistical analysis, generally, revealed that the highest values of $\mathrm{N}, \mathrm{P}, \mathrm{K}, \mathrm{Ca}$ and $\mathrm{Mg}$ and the lowest values of $\mathrm{Na}$ and $\mathrm{Cl}$ of coriander were achieved by spraying coriander plants with selenium, nano-selenium, and glycine betaine under control treatment in both seasons.

\section{Fruit yield, fruit essential oil percentage} and oil yield:

Regarding the effect of salt stress on fruit yield per plant, the results of fruit essential oil percentages and essential oil yield of coriander plants shown in Table (8). The results showed that fruit yield per plant and essential oil yield were significantly decreased with increasing level of salinity up to the highest concentration in both seasons. On the other hand, essential oil percentage increased with raising salinity levels up to the highest concentration in both seasons. The reason behind fruit yield reduction under salinity was inadequate photosynthesis owing to stomatal closure and consequently limited carbon dioxide uptake (Zhu, 2001). The obtained results on fruit yield reduction were in accordance with those reported by Ashraf and Orooj (2006) on ajwain and Neffati et al. (2011) on coriander.

The increment of essential oil percentage under salt stress could be due to a higher oil gland density (Charles et al., 1990). Also, salinity might affect the essential oil accumulation indirectly through its impact on either net assimilation or the partitioning of assimilation growth and differentiation processes (Charles et al., 1990). Neffati et al. (2011) found that the oil yield of coriander fruit based on the dry weight was increased 


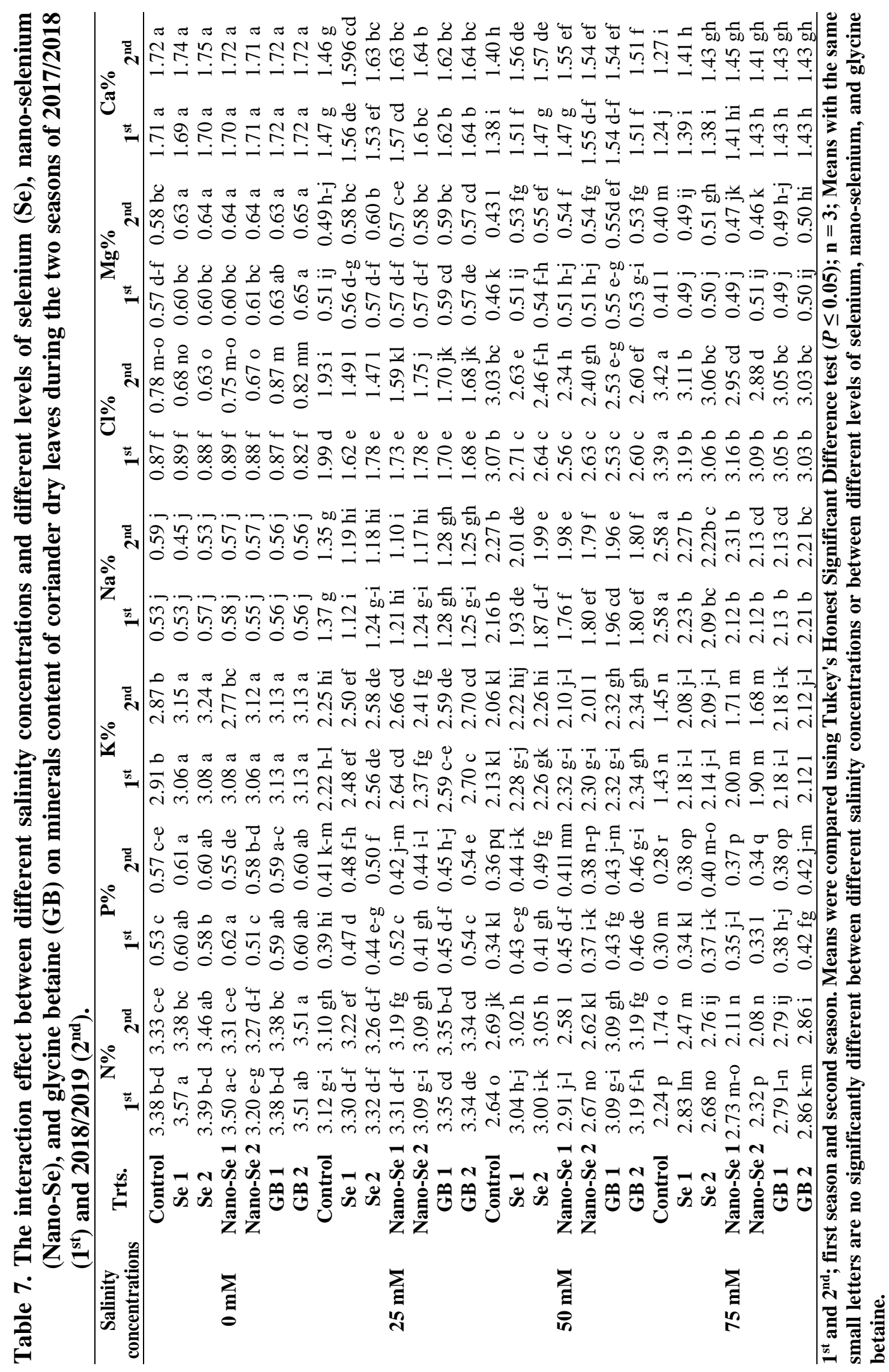




\section{R.G. El-Kinany et al.}

Table 8. The main effect of different salinity concentrations and different levels of selenium (Se), nano-selenium (Nano-Se), and glycine betaine (GB) on the fruit yield per plant, fruit essential oil percentage and essential oil yield of coriander during the two seasons of 2017/2018 $\left(1^{\text {st }}\right)$ and 2018/2019 $\left(2^{\text {nd }}\right)$.

\begin{tabular}{|c|c|c|c|c|c|c|}
\hline \multirow[t]{2}{*}{ Saline water } & \multicolumn{2}{|c|}{$\begin{array}{l}\text { Fruit yield per plant } \\
\text { (g/plant) }\end{array}$} & \multicolumn{2}{|c|}{$\begin{array}{c}\text { Fruit essential oil } \\
(\%)\end{array}$} & \multicolumn{2}{|c|}{$\begin{array}{c}\text { Essential oil yield } \\
(\mu \mathrm{l} / \mathrm{g})\end{array}$} \\
\hline & $1^{\text {nd }}$ & $2^{\text {nd }}$ & $1^{\text {nd }}$ & $2^{\text {nd }}$ & $1^{\text {nd }}$ & $2^{\text {nd }}$ \\
\hline \multicolumn{7}{|c|}{ Salt stress } \\
\hline $\mathbf{0 ~ m M}$ & $2.51 \mathrm{~A}$ & $2.47 \mathrm{~A}$ & $1.07 \mathrm{C}$ & $1.10 \mathrm{C}$ & $26.70 \mathrm{~A}$ & $27.07 \mathrm{~A}$ \\
\hline $25 \mathrm{mM}$ & $2.32 \mathrm{~B}$ & $2.30 \mathrm{~B}$ & $1.14 \mathrm{~B}$ & $1.15 \mathrm{~B}$ & $26.34 \mathrm{~A}$ & $26.51 \mathrm{~B}$ \\
\hline $50 \mathrm{mM}$ & $1.73 \mathrm{C}$ & $1.67 \mathrm{C}$ & $1.16 \mathrm{~A}$ & $1.17 \mathrm{~B}$ & $20.16 \mathrm{~B}$ & $19.54 \mathrm{C}$ \\
\hline $75 \mathrm{mM}$ & $1.12 \mathrm{D}$ & $1.11 \mathrm{D}$ & $1.19 \mathrm{~A}$ & $1.19 \mathrm{~A}$ & $13.23 \mathrm{C}$ & $13.17 \mathrm{D}$ \\
\hline \multicolumn{7}{|c|}{ Selenium, nano-selenium, and glycine betaine } \\
\hline Control & $1.57 \mathrm{D}$ & $1.56 \mathrm{D}$ & $1.11 \mathrm{C}$ & $1.14 \mathrm{C}$ & $17.31 \mathrm{D}$ & $17.65 \mathrm{D}$ \\
\hline Se 1 & $2.05 \mathrm{~B}$ & $1.99 \mathrm{~B}$ & $1.14 \mathrm{~A}-\mathrm{C}$ & $1.16 \mathrm{~A}-\mathrm{C}$ & $23.25 \mathrm{~B}$ & $22.93 \mathrm{~B}$ \\
\hline Se 2 & $2.00 \mathrm{~B}$ & $1.98 \mathrm{~B}$ & $1.16 \mathrm{AB}$ & $1.17 \mathrm{AB}$ & $22.63 \mathrm{~B}$ & $22.48 \mathrm{~B}$ \\
\hline Nano-Se 1 & $1.80 \mathrm{C}$ & $1.76 \mathrm{C}$ & $1.14 \mathrm{BC}$ & $1.15 \mathrm{BC}$ & $20.59 \mathrm{C}$ & $20.45 \mathrm{C}$ \\
\hline Nano-Se 2 & $1.74 \mathrm{C}$ & $1.72 \mathrm{C}$ & $1.12 \mathrm{BC}$ & $1.14 \mathrm{C}$ & $20.25 \mathrm{C}$ & $20.08 \mathrm{C}$ \\
\hline GB 1 & $2.07 \mathrm{~B}$ & $2.03 \mathrm{~B}$ & $1.14 \mathrm{BC}$ & $1.15 \mathrm{~A}-\mathrm{C}$ & $22.74 \mathrm{~B}$ & $22.90 \mathrm{~B}$ \\
\hline GB 2 & $2.20 \mathrm{~A}$ & $2.17 \mathrm{~A}$ & $1.17 \mathrm{~A}$ & $1.17 \mathrm{~A}$ & $24.48 \mathrm{~A}$ & $24.54 \mathrm{~A}$ \\
\hline
\end{tabular}

$1^{\text {st }}$ and $2^{\text {nd }}$; first season and second season. Means were compared using Tukey's Honest Significant Difference test $(P \leq 0.05) ; n=3$; Means with the same capital letters are no significantly different between different salinity concentrations or between different levels of selenium, nano-selenium, and glycine betaine.

by 77 and $84 \%$ at 50 and $75 \mathrm{mM} \mathrm{NaCl}$, respectively compared with control. The aforementioned results of increasing fruit essential oil percentage under salt stress were in agreement with Ben Taarit et al. (2009) on sage and Karray-Bouraoui et al. (2009) on Mentha pulegium. On the other hand, the reduction in essential oil yield per plant under salt stress may be attributed to the reduction in leaf area and photosynthesis which lead to the reduction of the number of fruits per umbrella then decreasing fruit yield per plant.

In relation to the effect of different selenium rates, nano-selenium, and glycine betaine on fruit yield per plant, fruit essential oil percentage and essential oil yield per plant of coriander plants, the data in Table (8) indicated that spraying the coriander plants with selenium, nano-selenium, and glycine betaine significantly increased fruit yield per plant, fruit essential oil percentage and essential oil yield as compared to control treatment and the highest mean values were observed at $10 \mathrm{mM}$ glycine betaine.
This improvement in fruit yield per plant, fruit essential oil percentage and essential oil yield of coriander plants due to glycine betaine application would be resulted from the beneficial effect of glycine betaine on growth and metabolism and its role as an osmoprotectant. These results were relatively similar to that reported by Sadaghiani et al. (2019) on chamomile. Also, selenium treatment resulted in an increase in fruit yield and that might be due to its role in increasing photosynthesis rate which causes more seed growth and conservation. Boldrin et al. (2013) found that foliar application with selenium increased grain yield of rice plants.

The effect of interaction between the different salinity concentrations and different rates of selenium, nano-selenium, and glycine betaine on fruit yield per plant, fruit essential oil percentage and essential oil yield of coriander plants were significant during both seasons (Table 9). The statistical analysis, generally, revealed that the highest value of fruit yield per plant was observed for the control combined with $10 \mathrm{mM}$ 
Table 9. The interaction effect between different salinity concentrations and different levels of selenium (Se), nano-selenium (Nano-Se), and glycine betaine (GB) on the fruit yield per plant, fruit essential oil (\%) and essential oil yield of coriander plants during the two seasons of 2017/2018 $\left(1^{\text {st }}\right)$ and $2018 / 2019\left(2^{\text {nd }}\right)$.

\begin{tabular}{|c|c|c|c|c|c|c|c|}
\hline \multirow{2}{*}{$\begin{array}{c}\text { Salinity } \\
\text { concentrations }\end{array}$} & \multirow[t]{2}{*}{ Trts. } & \multicolumn{2}{|c|}{$\begin{array}{l}\text { Fruit yield per plant } \\
\text { (g/plant) }\end{array}$} & \multicolumn{2}{|c|}{$\begin{array}{c}\text { Fruit essential oil } \\
(\%)\end{array}$} & \multicolumn{2}{|c|}{$\begin{array}{l}\text { Essential oil yield } \\
(\mu \mathrm{l} / \mathrm{g})\end{array}$} \\
\hline & & $1^{\text {st }}$ & $2^{\text {nd }}$ & $\mathbf{1}^{\text {st }}$ & $2^{\text {nd }}$ & $1^{\text {st }}$ & $2^{\text {nd }}$ \\
\hline \multirow{7}{*}{$0 \mathrm{mM}$} & Control & $2.38 \mathrm{de}$ & $2.43 \mathrm{c}-\mathrm{f}$ & $1.02 \mathrm{~g}$ & $1.09 \mathrm{~h}-\mathrm{j}$ & 24.57 de & $26.63 \mathrm{a}-\mathrm{c}$ \\
\hline & Se 1 & $2.52 \mathrm{~cd}$ & 2.50 a-d & $1.09 \mathrm{e}-\mathrm{g}$ & $1.12 \mathrm{f}-\mathrm{i}$ & $27.36 \mathrm{a}-\mathrm{c}$ & 27.99 a-c \\
\hline & Se 2 & $2.68 \mathrm{ab}$ & $2.70 \mathrm{a}$ & $1.05 \mathrm{fg}$ & $1.13 \mathrm{~d}-\mathrm{h}$ & 29.25 a & $29.11 \mathrm{a}$ \\
\hline & Nano-Se 1 & 2.29 ef & $2.30 \mathrm{~d}-\mathrm{g}$ & $1.09 \mathrm{e}-\mathrm{g}$ & $1.08 \mathrm{ij}$ & 24.14 ef & 25.44 c-e \\
\hline & Nano-Se 2 & $2.20 \mathrm{f}$ & $2.13 \mathrm{~g}-\mathrm{i}$ & $1.05 \mathrm{fg}$ & $1.0633 \mathrm{j}$ & 25.00 c-e & $24.06 \mathrm{~d}-\mathrm{f}$ \\
\hline & GB 1 & 2.65 bc & $2.57 \mathrm{a}-\mathrm{c}$ & $1.03 \mathrm{~g}$ & $1.0933 \mathrm{~h}-\mathrm{j}$ & $27.12 \mathrm{a}-\mathrm{c}$ & $27.96 \mathrm{a}-\mathrm{c}$ \\
\hline & GB 2 & $2.82 \mathrm{a}$ & $2.67 \mathrm{ab}$ & 1.14 c-e & $1.1067 \mathrm{~g}-\mathrm{j}$ & 29.45 a & $28.32 \mathrm{ab}$ \\
\hline \multirow{7}{*}{$25 \mathrm{mM}$} & Control & 1.92 gh & $1.97 \mathrm{ij}$ & $1.12 \mathrm{~d}-\mathrm{f}$ & 1.1467 c-g & 21.44 g-i & $22.22 \mathrm{fg}$ \\
\hline & Se 1 & 2.42 de & 2.37 c-f & 1.14 c-e & 1.1533 c-g & $27.66 \mathrm{~b}$ & $27.32 \mathrm{a}-\mathrm{c}$ \\
\hline & Se 2 & 2.43 de & $2.43 \mathrm{c}-\mathrm{f}$ & $1.17 \mathrm{a}-\mathrm{d}$ & 1.18 a-e & $27.74 \mathrm{ab}$ & 28.05 a-c \\
\hline & Nano-Se 1 & 2.33 ef & $2.27 \mathrm{e}-\mathrm{g}$ & 1.14 c-e & 1.1533 c-g & 27.29 a-c & 26.65 a-c \\
\hline & Nano-Se 2 & $2.22 \mathrm{f}$ & $2.23 \mathrm{f}-\mathrm{h}$ & $1.12 \mathrm{~d}-\mathrm{f}$ & 1.1467 c-g & 25.74 b-e & 26.32 b-d \\
\hline & GB 1 & 2.38 de & $2.33 \mathrm{~d}-\mathrm{g}$ & $1.12 \mathrm{~d}-\mathrm{f}$ & $1.1267 \mathrm{e}-\mathrm{h}$ & $26.62 \mathrm{~b}-\mathrm{d}$ & $26.76 \mathrm{a}-\mathrm{c}$ \\
\hline & GB 2 & $2.50 \mathrm{~cd}$ & 2.47 b-e & 1.16 a-e & 1.18 a-e & $27.93 \mathrm{ab}$ & $28.28 \mathrm{ab}$ \\
\hline \multirow{7}{*}{$50 \mathrm{mM}$} & Control & $1.28 \mathrm{~m}$ & 1.19 ор & $1.15 \mathrm{~b}-\mathrm{e}$ & 1.1433 c-g & $14.80 \mathrm{~lm}$ & $14.00 \mathrm{kl}$ \\
\hline & Se 1 & $1.92 \mathrm{gh}$ & $1.79 \mathrm{jk}$ & 1.16 a-e & $1.17 \mathrm{a}-\mathrm{f}$ & $22.08 \mathrm{f}-\mathrm{h}$ & 20.85 gh \\
\hline & Se 2 & $1.78 \mathrm{hi}$ & $1.73 \mathrm{kl}$ & $1.18 \mathrm{a}-\mathrm{d}$ & 1.1767 a-e & 20.68 h-j & $20.22 \mathrm{~g}-\mathrm{i}$ \\
\hline & Nano-Se 1 & $1.65 \mathrm{ij}$ & 1.55 l-n & $1.15 \mathrm{~b}-\mathrm{e}$ & $1.17 \mathrm{a}-\mathrm{f}$ & $19.51 \mathrm{ij}$ & 18.49 hi \\
\hline & Nano-Se 2 & $1.55 \mathrm{jk}$ & $1.58 \mathrm{~lm}$ & 1.16 a-e & 1.1533 c-g & 18.39 jk & $18.64 \mathrm{hi}$ \\
\hline & GB 1 & $1.90 \mathrm{gh}$ & $1.84 \mathrm{jk}$ & 1.16 a-e & 1.18 a-e & $21.91 \mathrm{f}-\mathrm{i}$ & $21.00 \mathrm{gh}$ \\
\hline & GB 2 & $2.05 \mathrm{~g}$ & $2.04 \mathrm{hi}$ & $1.19 \mathrm{a}-\mathrm{d}$ & $1.1933 \mathrm{a}-\mathrm{c}$ & $23.71 \mathrm{e}-\mathrm{g}$ & 23.57 ef \\
\hline \multirow{7}{*}{$75 \mathrm{mM}$} & Control & $0.68 \mathrm{o}$ & $0.64 \mathrm{r}$ & 1.14 c-e & $1.1600 \mathrm{~b}-\mathrm{f}$ & 8.43 o & $7.75 \mathrm{n}$ \\
\hline & Se 1 & $1.37 \mathrm{~lm}$ & $1.32 \mathrm{o}$ & $1.19 \mathrm{a}-\mathrm{d}$ & $1.1800 \mathrm{a}-\mathrm{d}$ & $15.90 \mathrm{l}$ & $15.54 \mathrm{k}$ \\
\hline & Se 2 & $1.08 \mathrm{n}$ & $1.05 \mathrm{pq}$ & $1.22 \mathrm{ab}$ & $1.1900 \mathrm{a}-\mathrm{c}$ & $12.85 \mathrm{mn}$ & $12.53 \mathrm{~lm}$ \\
\hline & Nano-Se 1 & $0.93 n$ & $0.92 \mathrm{q}$ & 1.16 a-e & $1.1933 \mathrm{a}-\mathrm{c}$ & $11.42 \mathrm{n}$ & $11.21 \mathrm{~m}$ \\
\hline & Nano-Se 2 & $0.98 \mathrm{n}$ & $0.95 \mathrm{q}$ & $1.17 \mathrm{a}-\mathrm{d}$ & $1.1867 \mathrm{a}-\mathrm{c}$ & $11.87 n$ & $11.30 \mathrm{~m}$ \\
\hline & GB 1 & $1.34 \mathrm{~lm}$ & 1.37 no & $1.23 \mathrm{a}$ & $1.2100 \mathrm{ab}$ & 15.321 & $15.89 \mathrm{jk}$ \\
\hline & GB 2 & $1.43 \mathrm{kl}$ & $1.52 \mathrm{mn}$ & $1.21 \mathrm{a}-\mathrm{c}$ & $1.2133 \mathrm{a}$ & $16.82 \mathrm{kl}$ & $18.00 \mathrm{ij}$ \\
\hline
\end{tabular}

$\mathbf{1}^{\text {st }}$ and $2^{\text {nd; }}$; first season and second season. Means were compared using Tukey's Honest Significant Difference test $(P \leq 0.05) ; n=3$; Means with the same capital letters are no significantly different between different salinity concentrations or between different levels of selenium, nano-selenium, and glycine betaine.

glycine betaine in the first season and 50 ppm selenium in the second season. Also, the highest value of essential oil yield was observed for the control combined with 10 $\mathrm{mM}$ glycine betaine in the first season and $50 \mathrm{ppm}$ selenium in the two seasons. The highest value of fruit essential oil percentage had been obtained as a result of the interaction between $75 \mathrm{mM} \mathrm{NaCl}$ treatment and foliar application with $5 \mathrm{mM}$ glycine betaine in the first season and $10 \mathrm{mM}$ glycine betaine in the second one.

\section{Fruit essential oil composition:}

The essential oil of coriander fruits extracted from control treatment $(0 \mathrm{mM}$
$\mathrm{NaCl}$ ) and control treatment sprayed with 10 $\mathrm{mM}$ glycine betaine and $50 \mathrm{ppm}$ selenium in both seasons were identified and illustrated in Table (10).

Data showed that the major component of the essential oil was linalool (40.81$49.74 \%$ ) based on the treatment. The other constituents were geranyl acetate (5.62$7.87 \%)$, camphor (5.19-8.25\%), $\delta$-terpinene (5.08-7.50\%) and $\alpha$-pinene (3.98-5.31\%) in both seasons. Our results were in accordance with those postulated by Bhuiyan et al. (2009) who found that coriander essential oil contained 53 main compounds, and the most important of these compounds were 
Table 10. Essential oil composition of $C$. sativum fruits extracted from control treatment $(0 \mathrm{mM} \mathrm{NaCl})$ and control treatment treated with $10 \mathrm{mM}$ glycine betaine (GB) and $50 \mathrm{ppm}$ selenium (Se) during the two seasons of 2017/2018 (1 ${ }^{\text {st }}$ ) and 2018/2019 ( $\left.{ }^{\text {nd }}\right)$.

\begin{tabular}{|c|c|c|c|c|c|c|}
\hline \multirow{3}{*}{ Essential oil composition } & \multicolumn{6}{|c|}{$\begin{array}{l}\text { Percentage of peaks of individual components relative to all peaks in } \\
\text { the chromatogram }\end{array}$} \\
\hline & \multicolumn{3}{|c|}{ Season 1} & \multicolumn{3}{|c|}{ Season 2} \\
\hline & Control & $\begin{array}{c}\text { Se } \\
(50 \text { ppm) }\end{array}$ & $\begin{array}{c}\text { GB } \\
(10 \text { ppm) }\end{array}$ & Control & $\begin{array}{c}\text { Se } \\
(50 \text { ppm) }\end{array}$ & $\begin{array}{c}\text { GB } \\
(10 \mathrm{ppm})\end{array}$ \\
\hline Linalool & $40.81 \mathrm{C}$ & $47.68 \mathrm{~B}$ & $49.74 \mathrm{~A}$ & $43.54 \mathrm{C}$ & 45.32 B & $47.47 \mathrm{~A}$ \\
\hline Geranyl acetate & $6.76 \mathrm{~B}$ & $7.87 \mathrm{~A}$ & $7.85 \mathrm{~A}$ & $5.62 \mathrm{~B}$ & $7.32 \mathrm{~A}$ & $7.12 \mathrm{~A}$ \\
\hline Camphor & $6.51 \mathrm{C}$ & $7.23 \mathrm{~B}$ & $8.16 \mathrm{~A}$ & $5.19 \mathrm{C}$ & $8.25 \mathrm{~A}$ & 7.95 B \\
\hline$\delta$-Terpinene & $5.08 \mathrm{~B}$ & $7.49 \mathrm{~A}$ & $7.5 \mathrm{~A}$ & $5.43 \mathrm{~B}$ & $6.84 \mathrm{~A}$ & $6.93 \mathrm{~A}$ \\
\hline a-Pinene & $3.98 \mathrm{C}$ & $4.48 \mathrm{~B}$ & $5.03 \mathrm{~A}$ & $4.3 \mathrm{~B}$ & $4.48 \mathrm{~B}$ & $5.31 \mathrm{~A}$ \\
\hline Geraniol & $3.32 \mathrm{~B}$ & $4.83 \mathrm{~A}$ & $3.63 \mathrm{~B}$ & $3.23 \mathrm{C}$ & $5.33 \mathrm{~A}$ & $4.48 \mathrm{~B}$ \\
\hline D-Limonene & $2.13 \mathrm{~B}$ & $2.03 \mathrm{~B}$ & $2.54 \mathrm{~A}$ & $2.00 \mathrm{~B}$ & $2.84 \mathrm{~A}$ & $2.6 \mathrm{~A}$ \\
\hline$\alpha$-Terpinolene & $0.72 \mathrm{~B}$ & $0.96 \mathrm{~A}$ & $0.77 \mathrm{~B}$ & $0.71 \mathrm{~B}$ & $0.73 \mathrm{~B}$ & $0.86 \mathrm{~A}$ \\
\hline Camphene & $0.66 \mathrm{C}$ & $1.12 \mathrm{~A}$ & $0.86 \mathrm{~B}$ & $0.53 \mathrm{~B}$ & $0.69 \mathrm{~B}$ & $0.91 \mathrm{~A}$ \\
\hline$\alpha$-Terpineol & $0.62 \mathrm{~B}$ & $0.65 \mathrm{~B}$ & $0.75 \mathrm{~A}$ & $0.63 \mathrm{~B}$ & $0.66 \mathrm{~B}$ & $0.74 \mathrm{~A}$ \\
\hline Borneol & $0.52 \mathrm{~B}$ & $0.75 \mathrm{~A}$ & $0.72 \mathrm{~A}$ & $0.54 \mathrm{C}$ & $0.85 \mathrm{~A}$ & $0.71 \mathrm{~B}$ \\
\hline Decanal & $0.52 \mathrm{~B}$ & $0.66 \mathrm{~A}$ & $0.68 \mathrm{~A}$ & $0.52 \mathrm{~B}$ & $0.63 \mathrm{~A}$ & $0.61 \mathrm{~A}$ \\
\hline$\beta$-Myrcene & $0.48 \mathrm{~B}$ & $0.53 \mathrm{~B}$ & $0.59 \mathrm{~A}$ & $0.44 \mathrm{C}$ & $0.52 \mathrm{~B}$ & $0.67 \mathrm{~A}$ \\
\hline$\beta$-Citronellol & $0.43 \mathrm{~B}$ & $0.47 \mathrm{~B}$ & $0.55 \mathrm{~A}$ & $0.47 \mathrm{~B}$ & $0.55 \mathrm{~A}$ & $0.52 \mathrm{~A}$ \\
\hline Sabinene & $0.27 \mathrm{~B}$ & $0.31 \mathrm{~A}$ & $0.34 \mathrm{~A}$ & $0.20 \mathrm{~B}$ & $0.27 \mathrm{~A}$ & $0.25 \mathrm{~A}$ \\
\hline 2-Pentadecanone, 6,10,14-trimethyl & $0.15 \mathrm{~B}$ & $0.19 \mathrm{~A}$ & $0.18 \mathrm{~A}$ & $0.12 \mathrm{~B}$ & $0.21 \mathrm{~A}$ & $0.22 \mathrm{~A}$ \\
\hline Hexadecanoic acid & $0.13 \mathrm{~B}$ & $0.13 \mathrm{~B}$ & $0.15 \mathrm{~A}$ & $0.12 \mathrm{~B}$ & $0.15 \mathrm{~A}$ & $0.14 \mathrm{~A}$ \\
\hline Dodecanal & $0.12 \mathrm{~B}$ & $0.16 \mathrm{~A}$ & $0.16 \mathrm{~A}$ & $0.10 \mathrm{~B}$ & $0.17 \mathrm{~A}$ & $0.16 \mathrm{~A}$ \\
\hline Tetradecanoic acid & $0.05 \mathrm{~A}$ & $0.06 \mathrm{~A}$ & $0.06 \mathrm{~A}$ & $0.03 \mathrm{~B}$ & $0.05 \mathrm{~A}$ & $0.04 \mathrm{AB}$ \\
\hline$\gamma$-Terpinene & $0.04 \mathrm{~B}$ & $0.11 \mathrm{~A}$ & $0.05 \mathrm{~B}$ & $0.02 \mathrm{~B}$ & $0.04 \mathrm{~B}$ & $0.09 \mathrm{~A}$ \\
\hline
\end{tabular}

$1^{\text {st }}$ and $2^{\text {nd }}$; first season and second season. Means having the same letter (s) within the same row are not significantly different according to LSD for all-pairwise comparisons test at $5 \%$ level of probability.

according to their levels of existence are linalool (37.7\%) and geranyl acetate (17.6\%). The chemical composition of the oil varies according to the different treatments with foliar application of selenium and glycine betaine. Foliar application of $10 \mathrm{mM}$ glycine betaine was the most effective treatment compared to the other treatments on increasing $\alpha$-pinene (5.03 and 5.31\%) and linalool (49.74 and 49.47\%) for the first and second season, respectively. Also, selenium and glycine betaine treatments were more effective treatments as compared to the control on increasing $\delta$ terpinene and geranyl acetate contents (7.49 and 7.50 and 6.84 and 6.93\%) and (7.87 and 7.85 and 7.32 and $7.12 \%$ ) for the first and second season, respectively. The highest values of camphor were recorded at $10 \mathrm{mM}$ glycine betaine $(8.16 \%)$ in the first season and $50 \mathrm{ppm}$ selenium (8.25\%) in the second season.

For the rest of the essential oil composition data showed that there were no significant differences between glycine betaine and selenium on increasing sabinene, decanal, dodecanal and 2-pentadecanone, 6,10,14-trimethyl in both seasons. High values of camphene, $\gamma$-terpinene, and $\alpha$ - 
terpinolene were recorded at $50 \mathrm{ppm}$ selenium in the first season and $10 \mathrm{mM}$ glycine betaine in the second season. Also, high values of $\beta$-myrcene, D-limonene and $\alpha$-terpineol were recorded at $10 \mathrm{mM}$ glycine betaine in both seasons and $50 \mathrm{ppm}$ selenium for D-limonene in the second season. Moreover, high values of $\beta$-citronellol and hexadecanoic acid were recorded at $10 \mathrm{mM}$ glycine betaine in both seasons and $50 \mathrm{ppm}$ selenium in the second season. Also, high values of borneol $\mathrm{L}$ and geraniol were recorded at $50 \mathrm{ppm}$ selenium in both seasons and $10 \mathrm{mM}$ glycine betaine in the first one for borneol L. Furthermore, there was no significant difference between control, selenium and glycine betaine in increasing tetradecanoic acid in the first season, but application of selenium at50 ppm resulted in the highest value in the second season. Generally, the application of growth regulators such as selenium and glycine betaine induce the synthesis of biologically active compounds and improves the pharmaceutical potential of the plant.

\section{CONCLUSION}

The results cleared that coriander vegetative growth, fruit yield, chlorophyll index, nitrogen, phosphorus, potassium content in leaves, essential oil percentages and its major components were significantly affected by salt stress. Exogenous applications of selenium and glycine betaine could improve the tolerance of coriander to salt stress. Applications of selenium and glycine betaine treatments increased fresh matter in coriander plants grown at saltstress conditions compared to nano selenium and control treatment by altering the contents of proline, ascorbic acid, and photosynthesis rate. Also, the exogenous application of selenium and glycine betaine enhanced the major constituents of coriander essential oil; linalool, geranyl acetate, camphor, $\delta$ terpinene, and $\alpha$-pinene. Therefore, farmers might enhance the growth, yield and essential oil composition of coriander plants after applications of selenium and exogenous glycine betaine under salinity stress.

\section{Acknowledgment:}

The authors would like to thank Prof. Dr. Said Gaber, Emeritus Professor of Horticulture, Faculty of Agriculture, Damanhour University for his constructive comments and revision of the manuscript.

\section{REFERENCES}

Abdel-Mawgoud, A.M.R. (2017). Soil and Foliar Applications of Glycinebetaine Ameliorate Salinity Effects on Squash Plants Grown under Bahraini conditions. Middle East J., 6(2):315-322.

Agboma, P.C; Peltonen-Sainio, P.; Hinkkanen, R. and Peh, E. (1996). Effect of foliar applied glycinebetaine on yield components of droughtstressed tobacco (Nicotiana tabacum L). Exp. Agric., 33:345-352.

Ahmad, P.; Hakeem, K.R.; Kumar, A.; Ashraf, M. and Akram, N.A. (2012). Salt induced changes in photosynthetic activity and oxidative defense system of three cultivars of mustard (Brassica juncea L.). African J. Biotech., 11(11): 2694-2703.

Al-Kazzaz, A.G.M. (2018). Effect of salinity stress and selenium spraying on broad bean plant Vicia faba L. Plant Archives, 18(2):2335-2339.

Asgari-Targhi, G.; Iranbakhsh, A. and Ardebili, Z.O. (2018). Potential benefits and phytotoxicity of bulk and nanochitosan on the growth, morphogenesis, physiology, and micropropagation of Capsicum annuum. Plant Physio. and Biochem., 127:393-402.

Ashraf, M. and Orooj, A. (2006). Salt stress effects on growth, ion accumulation and seed oil concentration in an arid zone traditional medicinal plant ajwain (Trachyspermum ammi [L.] Sprague). J. Arid Enviro., 64(2):209-220.

Ashraf, M. and Foolad, M.R. (2007). Roles of glycine betaine and proline in improving plant abiotic stress resistance. Environ. Exp. Bot., 59(2):206-216. 


\section{R.G. El-Kinany et al.}

Baki, G.A.E.; Siefritz, F.; Man, H.M.; Weiner, H.; Kaldenhoff, R. and Kaiser, W.M. (2000). Nitrate reductase in Zea mays L. under salinity. Plant, Cell \& Environment, 23(5):515-521.

Bates, L.S.; Waldren, R.P. and Teare, I.D. (1973). Rapid determination of free proline for water-stress studies. Plant and Soil, 39(1):205-210.

Beltagi, M.S. (2008). Exogenous ascorbic acid (vitamin C) induced anabolic changes for salt tolerance in chick pea (Cicer arietinum L.) plants. African J. Plant Sci., 2(10):118-123.

Ben Taarit, M.; Msaada, K.; Hosni, K.; Hammami, M.; Kchouk, M. E. and Marzouk, B. (2009). Plant growth, essential oil yield and composition of sage (Salvia officinalis L.) fruits cultivated under salt stress conditions. Industrial Crops and Product., 30(3): 333-337.

Bhuiyan, M.N.I.; Begum1, J. and Sultana, M. (2009). Chemical composition of leaf and seed essential oil of Coriandrum sativum L. from Bangladesh. Bangladesh J. Pharmacol., 4(2):150-153.

Boghdady, M.S.; Desoky, E.M.; Azoz, S.N.; Dalia, M. and Nassar, A. (2017). Effect of selenium on growth, physiological aspects and productivity of faba bean (Vicia faba L.). Egypt. J. Agron., 39(1):83- 97.

Boldrin, P.F.; Faquin, V.;. Ramos, S.J.; Boldrin, K.V.; Avila, F.W. and Guilherm, L.R.G. (2013). Soil and foliar application of selenium in rice biofortification. J. Food Composition and Analysis, 31(2):238-244.

Charles, D.J.; Joly, R.J. and Simon J.E. (1990). Effect of osmotic stress on the essential oil content and composition of peppermint. Phytochemistry, 29(9): 2837-2840.

Chen, T.H. and Murata, N. (2002). Enhancement of tolerance of abiotic stress by metabolic engineering of betaines and other compatible solutes. Curr. Opin. Plant Biol., 5(3):250-257.

CoStat (2008). CoStat program, version 6.4. CoHort Software, Monterey, CA., USA.

Cottenie, A.; Verloo, M.; Kiekens, L.; Velgh, G. and Camerlynk, R. (1982). Chemical Analysis of Plants and Soils. Lab. Agroch. State Univ. Gent, Belgium., 63:44-45.

Demiral, T. and Türkan, I. (2006). Exogenous glycine betaine affects growth and proline accumulation and retards senescence in two rice cultivars under $\mathrm{NaCl}$ stress. Envir. and Exp. Bot., 56(1):72-79.

Diao, M.; Ma, L.; Wang, J.; Cui, J.; Fu, A. and Liu, H.Y. (2014). Selenium promotes the growth and photosynthesis of tomato seedlings under salt stress by enhancing chloroplast antioxidant defense system. J. Plant Growth Regu., 33(3): 671-682.

Djanaguiraman, M.; Prasad, P.V.V. and Seppanen, M. (2010). Selenium protects sorghum leaves from oxidative damage under high temperature stress by enhancing antioxidant defense system. Plant Physiol. and Biochem., 48(12): 999-1007.

Dunlap, J. R and Binzel, M.L. (1996). NaCl reduced indole-3-acetic acid levels in the roots of tomato plants independent of stress induced abscisic acid. Plant Physiol., 112(1):379-384.

El-Batal, A.I.; Thabet, N.M.; Osman, A.; Abdel Ghaffar, A.B. and Azab, K.S. (2012). Amelioration of oxidative damage induced in gamma irradiated rats by nano selenium and lovastatin mixture. World Appl. Sci. J., 19(7):962- 971.

Elhindi, K.M.; El-Hendawy, S.; AbdelSalam, E.; Schmidhalter, U.; Rehman, S. and Hassan, A.A. (2016). Foliar application of potassium nitrate affects the growth and photosynthesis in coriander (Coriander sativum L.) plants under salinity. Progress in Nutrition., 18(1):63-73. 
Emam, M.M. and Helal, N.M. (2008). Vitamins minimize the salt-induced oxidative stress hazards. Australian J. of Basic and Applied Sciences., 2(4):110119.

Evans, W.C (2002). Trease and Evans: Pharmacognocy. Fifteenth International Edition, W.B. Saunders, Edinburgh, London, New York. 262.

Fidalgo, F.; Santos, A.; Santos, I. and Salema, R. (2004). Effects of long-term salt stress on antioxidant defence systems, leaf water relations and chloroplast ultrastructure of potato plants. Annals of Appl. Bio., 145:185-192.

Gunther, G. (1961). The Essential Oils. Nastrand Press, New York, USA.

Habib, N.; Ashraf, M.; Ali, Q. and Perveen, R. (2012). Response of salt stressed okra (Abelmoschus esculentus Moench) plants to foliar-applied glycine betaine and glycine betaine containing sugar beet extract. South African. J. Bot., 83:151158.

Harinasut, P.; Tsutsui, K.; Takabe, T.; Nomura, M. and Kishitani, S. (1996). Exogenous glycine betaine accumulation and increased salt tolerance in rice seedlings. Biosci Biotechnol Biochem., 60(2):366-368.

Hayat, S.; Hayat, Q.; Alyemeni, M.N.; Wani, A.S.; Pichtel, J. and Ahmad, A. (2012). Role of proline under changing environments. Plant Signaling Behav., 7(11):1456-1466.

Heidari, M. (2012). Effects of salinity stress on growth, chlorophyll content and osmotic components of two basil (Ocimum basilicum L.) genotypes. African J. Biotech., 11(2):379-384.

Heidari. M and Akbari, T. (2012). Effect of salinity stress on photosynthesis pigments and osmotic components of two marigold (Tagetes patula L.) genotypes. In UMT $11^{\text {th }}$ international annual symposium on sustainability science and management, Terengganu, Malaysia., 204-209.

Heuer, B. (2003). Influence of exogenous application of proline and glycine betaine on growth of salt-stressed tomato plants. Plant Science., 165(4): 693-699.

Hu, K.; Zhang, L.; Wang, J. and You, Y. (2013). Influence of selenium on growth, lipid peroxidation and antioxidative enzyme activity in melon (Cucumis melo L.) seedlings under salt stress. Acta Soci Botan Poloniae, 82(3): 193-197.

Huang, B.; Zhang, J.; Hou, J. and Chen, C. (2003). Free Radical. Biol. Medic., 35(7): 805-813.

Jackson, M.L. (1967). Soil Chemical Analysis. Prentice Hall of India Pvt. Ltd., New Delhi; 205 p.

Jiang, C.; Zu, C.; Lu, D.; Zheng, Q.; Shen, J. and Wang, H. (2017). Effect of exogenous selenium supply on photosynthesis, $\mathrm{Na}^{+}$accumulation and antioxidative capacity of maize (Zea mays L.) under salinity stress. Nature Publishing Group, 1-14.

Jones, B.J. (1991). Kjeldahl Method for Nitrogen Determination. Micro-Macro Publishing, USA, 79 p.

Kanechi, M.; Hikosaka, Y. and Uno, Y. (2013). Application of sugarbeet pure and crude extracts containing glycinebetaine affects root growth, yield, and photosynthesis of tomato grown during summer. Sci. Hortic., 152:9-15.

Karimi, M.; De Meyer, B. and Hilson, P. (2005). Modular cloning in plant cells. Trends Plant Sci., 10(3):103-105.

Karray-Bouraoui, N.; Rabhi, M.; Neffati, M.; Baldan, B.; Ranieri, A.; Marzouk, B.; Lachaâl, M. and Smaoui, A. (2009). Salt effect on yield and composition of shoot essential oil and trichome morphology and density on leaves of Mentha pulegium. Industrial Crops and Product, 30(3):338-343. 


\section{R.G. El-Kinany et al.}

Kaur, S. and Nayyar, H. (2015). Selenium fertilization to salt-stressed mungbean (Vigna radiata (L.) Wilczek) plants reduces sodium uptake, improves reproductive function, pod set and seed yield. Scientia Horticulturae, 100(197):304-17.

Kaya, C.; Sönmez, O.; Aydemir, S. and Dikilitaş, M. (2013). Mitigation effects of glycinebetaine on oxidative stress and some key growth parameters of maize exposed to salt stress. Turkish J. Agric. and Fores., 37(2):188-194.

Khaled, H. and Fawy, H.A. (2011). Effect of different levels of humic acids on the nutrient content, plant growth, and soil properties under conditions of salinity. Soil \& Water Res., 6 (1):21-29.

Khalil. S.E. and El-Noemani, A.A. (2012). Effect of irrigation intervals and exogenous proline application in improving tolerance of garden cress plant (Lepidium sativum L.) to water stress. Journal of Applied Sciences Research, 8(1):157-167.

Khan, M.M.; Al-Mas’oudi, R.S.; Al-Said, F. and Khan, I. (2013). Salinity effects on growth, electrolyte leakage, chlorophyll content and lipid peroxidation in cucumber (Cucumis sativus L.). In International Conference on Food and Agricultural Sciences Malaysia: IACSIT Press., 55:28-32.

Kong, L.; Wang, M. and Bi, D. (2005). Selenium modulates the activities of antioxidant enzymes, osmotic homeostasis and promotes the growth of sorrel seedlings under salt stress. Plant Growth Regulation., 45(2):155-163.

Langroudi, M.E. and Sedaghathoor, S. (2012). Effect of Different Media and Salinity Levels on Growth Traits of Rosemary (Rosmarinus officinalis L.). Department of Horticulture, Faculty of Agriculture, Islamic Azad University, Rasht Branch, Iran. American-Eurasian J. Agric. and Environ. Sci., 12 (9): 11341142.
Liu, X.; Yang, Y.; Deng, X.; Li, M.; Zhang, W. and Zhao, Z. (2017). Effects of sulfur and sulfate on selenium uptake and quality of seeds in rapeseed (Brassica napus L.) treated with selenite and selenate. Environmental and Experimental Botany., 100(135):13-20.

Lopez, M.V. and Satti, S.M.E. (1996). Calcium and potassium-enhanced growth and yield of tomato under sodiumchloride stress. Plant Science., 114(1): 19-27.

Lutts, S.; Bouharmont, J. and Kine, J.M. (1999). Physiological characterization of salt-resistant rice (Oryza sativa L.) varieties differing in salinity resistance. J. Exp. Bot., 46:1843-1852.

Makela, P.; Jokinen, K.; Kontturi, M.; Peltonen-Sainio, P.; Pehu, E. and Somersalo, S. (1998). Foliar application of glycinebetaine - a novel product from sugar beet - as an approach to increase tomato yield. Indust. Crops Prod., 7(2): 139-148.

Makela, P.; Kontturi, M.; Pehu, E. and Somersalo, S. (1999). Photosynthetic response of drought- and salt-stressed tomato and turnip rape plants to foliarapplied glycine betaine. Physiol. Plant., 105(1):45-50.

Mastronardi, E.; Tsae, P.; Zhang, X.; Monreal, C. and DeRosa, M.C. (2015). Strategic role of nanotechnology in fertilizers: potential and limitations. In Nanotechnologies in Food and Agriculture. Springer, Cham., pp: 25-67.

Mazher. A.A.M.; Eid, R.A. and Abd ElAziz, N.G.A. (2006). Effect of Microbien under salt stress on modulation, growth and chemical constituents of Sesbania egyptiac in sandy soil. Bull NRC, Egypt, 31(3):247-268.

Molazem. D.; Qurbanov, E.M. and Dunyamaliyev, S.A. (2010). Role of proline, $\mathrm{Na}$ and chlorophyll content in salt tolerance of corn (Zea mays) L. 
American-Eurasian J. Agric. \& Environ. Sci., 9(3):319-324.

Mostafakamal, S.; Yildirim, E.; Ekinci, M.; Turan, M.; Dursun, A.; Parlakova, F. and Kul, R. (2016). Exogenously Applied Glycine Betaine Regulates Some Chemical Characteristics and Antioxidative Defence Systems in Lettuce under Salt Stress. Hortic. Environ. Biotechnol., 57(3):225-231.

Mozafariyan, M.; Kamelmanesh, M.M. and Hawrylak-nowak, B. (2016). Ameliorative effect of selenium on tomato plants grown under salinity stress. Archives of Agronomy and Soil Science., 62(10):1368-1380.

Murata, N.; Mohanthy, P.S.; Hayashi, H. and Papageorgiou, G.C. (1992). Glycinebetaine stabilizes the association of extrinsic proteins with the photosynthetic oxygen-evolving PS-II complex against the inhibitory effects of $\mathrm{NaCl}$. FEBS Lett., 296(2):187-9.

Navarro. J.M.; BotellaCerda, M.A.A. and Martinez, V. (2001). Phosphorus uptake and translocation in salt-stressed melon plants. J. Plant Physio., 158(3):375-381.

Nawaz, F.; Ahmad, R.; Ashraf, M.Y.; Waraich, E.A. and Khan, S.Z. (2015). Effect of selenium foliar spray on physiological and biochemical processes and chemical constituents of wheat under drought stress. Ecotoxicology and Environmental Safety., 113:191-200.

Neffati, M. and Marzouk, B. (2009). Roots volatiles and fatty acids of coriander (Coriandrum sativum L.) grown in saline medium. Acta physiologiae Plantarum., 31(3):455-461.

Neffati, M.; Sriti, J.; Hamdaoui, G.; Kchouk, M.E. and Marzouk, B. (2011). Salinity impact on fruit yield, essential oil composition and antioxidant activities of Coriandrum sativum fruit extracts. Food Chemistry., 124(1):221-225.

Nejad Ebrahimi, S.; Hadian, J. and Ranjbar, H. (2010). Essential oil compositions of different accessions of Coriandrum sativum L. from Iran. Natural product research., 24(14):1287-1294.

Rahnama, A.; James, R.A.; Poustini, K. and Munns, R. (2010). Stomatal conductance as a screen for osmotic stress tolerance in durum wheat growing in saline soil. Funct. Plant Biol., 37(3):255-263.

Rhodes, D.; Rich, P.J.; Brunk, D.G.; Ju, G.C.; Rhodes, J.C.; Pauly, M.H. and Hansen, L.A. (1989). Development of two isogenic sweet corn hybrids differing for glycine betaine content. Plant Physiol., 91(3):1112-1121.

Ríos, J.J.; Rosales, M.A.; Blasco, B.; Cervilha, L.; Romero, L. and Ruiz, J.M. (2008). Bio fortification of Se and induction of the antioxidant capacity in lettuce plants. Sci. Hortic., 116(3):248255.

Sadaghiani, F.M.; Dehaghi, M.A.; Pirzad, A. and Fotokian, M.H. (2019). Variation in yield and biochemical factors of German chamomile (Matricaria recutita L.) under foliar application of osmolytes and drought stress conditions. Journal of Herbmed Pharmacology., 8(2):90-100.

Saeed, H.M.; Mirza, J. I. and Anjum, M.A. (2016). Glycinebetaine-induced modulation in some biochemical and physiological attributes of okra under salt stress. Pak. J. Bot., 48(6):2205-2210.

Sahib, N.G.; Anwar, F.; Gilani, A.H.; Hamid, A.A.; Saari, N. and Alkharfy, K.M. (2013). Coriander (Coriandrum sativum L.): A potential source of high value components for functional foods and nutraceuticals. A review. Phytotherapy Research., 27(10):14391456.

Seth, S.P.; Sharma, V. and Khandelwal, S.K. (2007). Effect of salinity on antioxidant enzymes in wheat. Indian J. Plant Physiol., 12(2):186-188.

Shaddad, M.A. (1990). The effect of proline application on the physiology of Raphanus sativus plants grown under 


\section{R.G. El-Kinany et al.}

salinity stress. Biol. Plant., 32(2):104112.

Shams, M.; Yildirim, E.; Ekinci, M.; Turan, M.; Dursun, A.; Parlakova, F. and Kul, R. (2016). Exogenously applied glycine betaine regulates some chemical characteristics and antioxidative defence systems in lettuce under salt stress. Hortic. Environ. Biotechnol., 57(3):225231.

Silva, F.; Ferreira, S.; Queiroz, J.A. and Domingues, F.C. (2011). Coriander (Coriandrum sativum L.) essential oil: its antibacterial activity and mode of action evaluated by flow cytometry. J. Medic Microbiol., 60(10):1479-1486.

Singh, J.P. (1988). A rapid method for determination of nitrate in soil and plant extracts. Plant soil., 110(1):137-139.

Soares, B.V.; Morais, S.M.; dos Santos Fontenelle, R.O.; Queiroz, V.A.; VilaNova, N.S.; Pereira, C.; Brito, E.S.; Neto, M.A.; Brito, E.H.; Cavalcante, C.S. and Castelo-Branco, D.S. (2012). Antifungal activity, toxicity and chemical composition of the essential oil of Coriandrum sativum L. fruits. Molecules, 17(7):8439-8448.
Wareing, P.F and Phillips, I.D.J. (1974). The control of growth and differentiation in plants. Pergamon Press L.td. Oxford.

Yadava, U.L. (1986). A rapid and nondestructive method to determine chlorophyll in intact leaves. Horticulture Science., 21(6):1449-1450.

Yamane, K.; Kawasaki, M.; Taniguchi, M. and Miyake, H. (2003). Differential effect of $\mathrm{NaCl}$ and polyethylene glycol on the ultra-structure of chloroplasts in rice seedlings. J. Plant physiol., 160(5): 573-575.

Yeo, A.R.; Lee, K.S.; Izard, P.; Boursier, P.J. and Flowers, T.J. (1991). Short and long term effects of salinity on leaf growth in Rice (Oryza sativa L.), J. Exp. Bot., 42(7):881-889.

Zheljazkov, V.D.; Pickett, K.M.; Caldwell, C.D.; Pincock, J.A.; Roberts, J.C. and Mapplebeck, L. (2008). Cultivar and sowing date effects on seed yield and oil composition of coriander in Atlantic Canada. Industrial Crops and Products, 28(1):88-94.

Zhu, J. K. (2001). Plant salt tolerance. Trends in Plant Science, 6(2):66-71.

\section{تحسين صفات النمو ومحصول الزيت الطيار و مكوناته والتركيب الكيميائي فى نباتات الكزبرة النامية تحت ظروف الإجهاد الملحي متأثره بالسلينيوم والنانوسلينيوم والجلايسين بيتائين ولئن

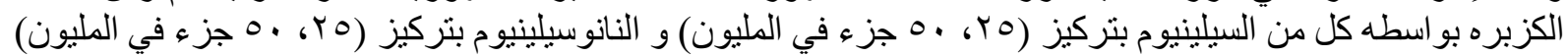

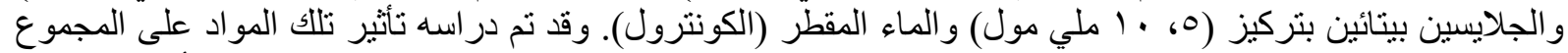

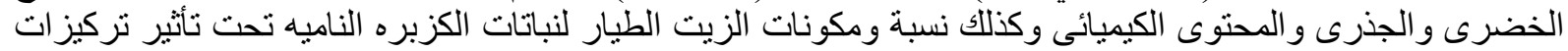

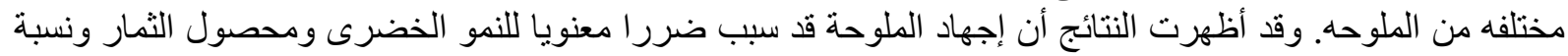




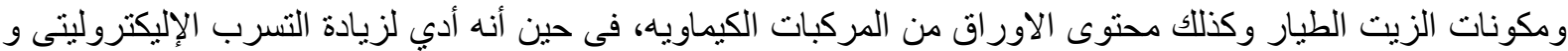

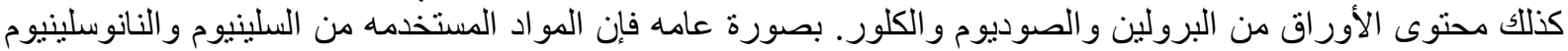

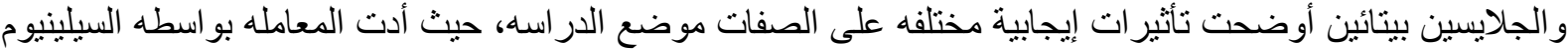

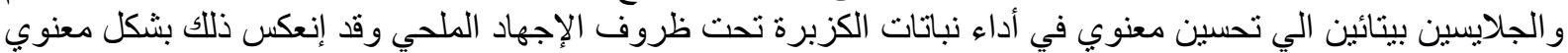
في زيادة جميع الصفات المدروسة مقارنة بالكونترول نباتئ 